Life Sciences Contributions 79
Royal Ontario Museum

A Review of the North American Hawk Moth

Genus Lapara (Lepidoptera: Sphingidae)

J. C. E. Riotte

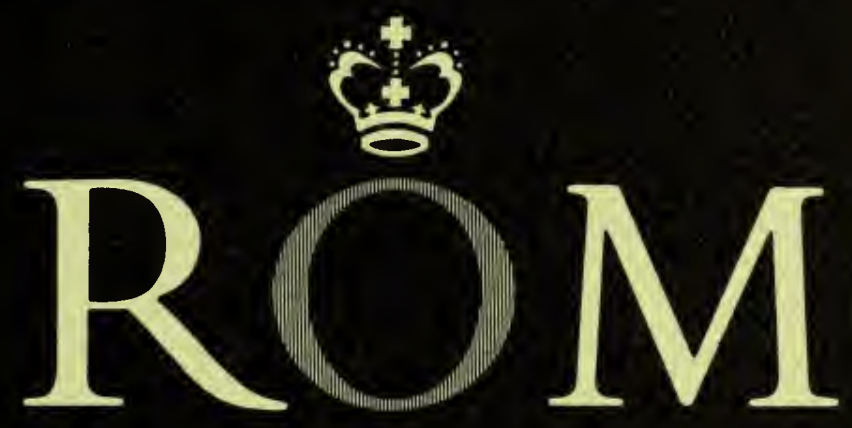


DEPARTWENT COPY 
LIFE SCIENCES CONTRIBUTIONS

ROYAL ONTARIO MUSEUM

NUMBER 79

J.C.E. RIOTTE

A Review of the North American

Hawk Moth Genus Lapara

(Lepidoptera: Sphingidae)

Publication date: 2 February 1972

Suggested citation: Life Sci. Contr., R. Ont. Mus. 
ROYAL ONTARIO MUSEUM

\section{PUBLICATIONS IN LIFE SCIENCES}

The Royal Ontario Museum publishes three series in the Life Sciences:

LIFE SCIENCES CONTRIBUTIONS, a numbered series of original scientific publications, including monographic works.

LIFE SCIENCES OCCASIONAL PAPERS, a numbered series of original scientific publications, primarily short and usually of taxonomic significance.

LIFE SCIENCES MISCELLANEOUS PUBLICATIONS, an unnumbered series of publications of varied subject matter and format.

All manuscripts considered for publication are subject to the scrutiny and editorial policies of the Life Sciences Editorial Board, and to review by persons outside the Museum staff who are authorities in the particular field involved.

LIFE SCIENCES EDITORIAL BOARD, 1971-1972

Chairman: P.C. SWANN

Director, Royal Ontario Museum

Editors: E. J. CROSSMAN

J. R. TAMSITT

J.C.E. RIOTTE is a Research Associate in the Department of Entomology and Invertebrate Zoology, Royal Ontario Museum.

PRICE : $\$ 2.00$

CThe Royal Ontario Museum, 1972

100 Queen's Park, Toronto, Canada

PRINTED BY MCKINNON MONCUR 


\section{CONTENTS}

Abstract, 1

Introduction, 1

Methods, 2

Lapara Walker, 3

Generic Diagnosis, 3

Original Description, 3

Summary of Comparative Morphology, 3

Systematic Position of Lapara, 5

Phylogenetic Relationships of Species, 6

Biology, 7

Key to Adults Based on External Features, 8

Key to Adults Based on Genitalic Features, 8

Key to Mature Larvae, 9

Lapara halicarnie (Strecker), 10

Lapara coniferarum (J.E. Smith), 13

Lapara bombycoides Walker, 17

Incerta sedis: Lapara pinea (Lintner), 23

Discussion, 25

Acknowledgments, 26

Literature Cited, 27

Figures, 31 
Digitized by the Internet Archive in 2011 with funding from University of Toronto 


\title{
A Review of the North American Hawk Moth Genus Lapara (Lepidoptera: Sphingidae)
}

\begin{abstract}
The status of Lapara species has long been in doubt. Examination of new material has produced additional evidence from the (adult) genitalia, head, epiphysis and pretarsus, as well as from the larval and pupal stages, confirming the validity of the three traditional species, L. halicarnie (Strecker), L. coniferarum (J. E. Smith) and $L$. bombycoides Walker.

The status of a fourth taxon, L. pinea (Lintner) remains uncertain. Described from two specimens with characteristics intermediate between $L$. coniferarum and $L$. bombycoides, it has not been recorded since its original discovery in 1859 .
\end{abstract}

\section{Introduction}

Moths of the North American sphingid genus Lapara occur over much of the eastern half of the continent, from Nova Scotia south to Florida and west to British Columbia and Nebraska. In their classical revision of the sphingids, Rothschild and Jordan (1903) assigned four species to Lapara: coniferarum, pineum [sic], bombycoides, and halicarniae [sic]. The status of these forms has been controversial among students of the Sphingidae for many years. The most directly opposing view is that of Forbes (1948), who suggested that, apart from L. halicarnie, the other taxa should be regarded only as races of a second species. Clearly, then, additional evidence to resolve these conflicting views has been needed.

My examination of specimens indicates that certain characters in this genus were not fully appreciated by previous workers. Enlarging upon these, I made a comparative study of specimens from many parts of the range of the genus and examined all available associated larval and pupal material. The evidence obtained adds strength to the view that there are three valid species of Lapara apparently sympatric over wide areas of their range. The status of a fourth taxon, L. pinea, is doubtful.

After the present paper had been submitted for publication, Hodges' (1971) monograph of the Sphingoidea appeared in print. His treatment of Lapara (ibid.: 72-76) is an improvement over Forbes (1948), especially in according full species status to both $L$. bombycoides and $L$. coniferarum. However, he placed $L$. halicarnie as a synonym of $L$. coniferarum, a conclusion not supported by my own findings. The present study also demonstrated that $L$. pinea is not clearly a synonym of $L$. bombycoides as Hodges indicates (ibid.: 75). 


\section{Methods}

For each species, the genitalia of a number of specimens from different populations representing widely separated portions of the range were dissected. Male genitalia were dissected in detail to separate the left valve so that it could be photographed and measured in a horizontal position. Each adult specimen dissected was photographed with Kodak infra-red-sensitive film (IR 135) producing a clearer definition of the wing pattern and other features, such as the clusters of white hairs at the tegulae of $L$. bombycoides, than does standard film. The head was denuded to examine the head structure and the labrum, and anterior legs were removed from some specimens and cleaned for examination of the epiphysis. In some the labial palpi were also removed, cleaned, and studied.

Localities and flight periods for specimens examined are cited under each species account. Full specimen data have been deposited in the library of the Royal Ontario Museum and are accessible there for reference. The abbreviations for sites of specimen deposition are as follows:

$\begin{array}{ll}\text { AMNH } & \text { The American Museum of Natural History } \\ \text { BM } & \text { British Museum (Natural History) } \\ \text { CLU } & \text { Clemson University, South Carolina } \\ \text { CM } & \text { Carnegie Museum } \\ \text { CNC } & \text { Canadian National Collection of Insects } \\ \text { FMNH } & \text { Field Museum of Natural History } \\ \text { FSCA } & \text { Florida State Collection of Arthropods } \\ \text { JGF } & \text { J. G. Franclemont, Cornell University } \\ \text { LEM } & \text { Lyman Entomological Museum } \\ \text { MCZ } & \text { Museum of Comparative Zoology } \\ \text { MSU } & \text { Michigan State University } \\ \text { NYSM } & \text { New York State Museum } \\ \text { OSM } & \text { Ohio State Museum } \\ \text { OSU } & \text { Ohio State University } \\ \text { ROM } & \text { Royal Ontario Museum } \\ \text { USNM } & \text { United States National Museum } \\ \text { WES } & \text { W. E. Sieker, Madison, Wisconsin } \\ \text { YPM or DCF } & \text { Yale Peabody Museum of Natural History, or } \\ & \text { D. C. Ferguson }\end{array}$




\section{Lapara Walker}

Lapara Walker, 1856, p. 232 (type: bombycoides); Clemens, 1859, p. 187; Beutenmüller, 1895, p. 309; Rothschild and Jordan, 1903, p. 150; Holland, 1903, p. 53; Rothschild and Jordan, 1907, p. 30; Wagner, 1913, p. 70; Draudt, 1931, p. 860; Forbes, 1948, p. 192.

Ellema Clemens, 1859, p. 187 (type: harrisii); Fernald, 1886, p. 82; J. B. Smith, 1888, p. 152, 206.

Exedrium Grote, 1882, p. 11 (type: halicarnie); J. B. Smith, 1888, p. 152.

Compared with other groups of Lepidoptera, the genus Lapara has enjoyed a relatively uncomplicated taxonomic and nomenclatorial history. Although the name was first used by Walker (1856) in association with the species bombycoides, the three species now included in Lapara were placed in other genera during the second half of the 19th century. There is no doubt, however, that Lapara has priority.

Rothschild and Jordan (1903: 150), in their monograph of the world sphingids, and Wagner in the Lepidopterorum Catalogus (1913: 70) gave complete bibliographies of earlier publications concerned with this group.

\section{GENERIC DIAGNOSIS}

Adult with antennae slender, subclavate, slightly longer than thorax, attenuate, and weakly hooked distally; proboscis short, the labial palpus small; pulvillus, paronychium with one lobe, and empodium present. Larva without caudal horn, with eight or nine pairs of labral setae. Pupa with tongue case concealed.

\section{ORIGINAL DESCRIPTION}

"Body rather slender; head small, short; proboscis moderately long; palpi very short; antennae slender, subclavate, hardly longer than the thorax, and attenuated but weakly hooked towards the tips; abdomen linear, fully twice the length of the thorax; legs slender; hind tibiae with four moderately long spurs; wings rather narrow, not long; fore wings almost straight in front, slightly rounded at the tips, straight and very oblique along the exterior border; interior border straight; second interior vein far nearer to the first than to the third; fourth very remote; hind wings rounded at tips" (Walker, 1856: 232).

\section{SUMMARY OF COMPARATIVE MORPHOLOGY}

Adult (Figs. 1-5, 10-20). The anterior wing has 11 veins and an oblique, evenly rounded outer margin; the posterior wing shows a typical sphingid venation, the outer margin is entire and rounded, but slightly excavated between $2 \mathrm{~d} \mathrm{~A}$ and $\mathrm{Cu}_{2}$.

The head is small, retracted; the vestiture forms an indistinct tuft between the antennae, which are slender, fusiform, widest beyond the middle, and terminate in a bent, ciliated seta; antennae biciliate in males, simple in females. The head (Fig. 1a-c) is trapezoidal in shape. The eyes are moderately lashed with blackish-brown bristles. The laterofrontal sutures are obscured by the convexity of the sides of the frons. The labrum is roughly triangular, and its shape is species specific (Fig. 2). 
The proboscis is short, much shorter than in other members of the tribe Sphingini, and the labial palpus is smaller; the pilifer is covered with short, stiff bristles. The small third segment of the labial palpus appears as a little knob with an apical pit containing sensory hairs (Fig. $3 a-c)$. This third segment is identical in the male and the female except in females of $L$. halicarnie, which have an elongated third segment (Fig. 3a), a character that distinguishes them from large coniferarum females occurring in the southern-most part of Mississippi.

The thorax is short and stout, rounded in front, and scarcely produced beyond the base of the anterior wings; vestiture thin but close.

The spines of the legs are not prominent; anterior tibia with one strongly developed and elongate apical spine; middle tibia with a pair of spurs, one short and one long; posterior tibia bearing a pair of subapical and a pair of apical spurs, one apical spur considerably longer than the others, especially in L. halicarnie; secondary spines may be present or absent on spurs. The tarsus of the middle leg lacks a comb, length of first segment approximately that of the other four segments combined.

The epiphysis is a distinguishing specific character in sphingids (Mooser, 1940: 426), and this structure on the anterior leg differs strikingly in the three species of Lapara (see Fig. 4).

The structure of the pretarsus is important for grouping sphingid genera and is also important for grouping the species of Lapara (Fig. 5):

$L$ halicarnie

L. coniferarum

L. bombycoides with well-developed pulvillus; paronychium with one strong lateral lobe; empodium one tubercle bearing a single seta (Fig. 5a);

with pulvillus much reduced; paronychium with one lateral lobe; empodium one tubercle bearing a single seta;

with pulvillus greatly reduced; paronychium rudimentary; empodium of anterior pretarsi of males two tubercles, each with one seta (Fig. 5b); empodium of other male and all female pretarsi, one tubercle bearing a single seta.

The abdomen is cylindrical and tapering, untufted; posterior edges of segments weakly spinulose.

In the male genitalia (Fig. 10) tegumen and vinculum are fused but visibly distinct; uncus pyramidal, blunt, with small rounded projection; gnathos bifid at tip but fused, usually blunt but more pointed in some specimens. Valve large, sacculus with prominent process. Aedoeagus extended caudally into a pointed process.

In the female genitalia (Figs. 15-18) signum absent on bursa copulatrix; ostium bursae oval.

Larva (Figs. 6-8, 21). The larvae of the three species resemble one another in lacking a caudal horn and in having a roughly triangular shaped head. Differences in colour and the number of labral setae, however, clearly separate them into two groups: L. halicarnie, of dull brown colour, with three pairs of additional labral setae (Figs. 21a-b, 6a, 7a); L. coniferarum and L. bombycoides, of green 
colour, with only two pairs of additional labral setae (Figs. $21 \mathrm{c}-\mathrm{d}, 6 \mathrm{~b}-\mathrm{c}, 7 \mathrm{~b}-\mathrm{c}$ ). Forbes (1923: 31) discussed the setae on the labrum of lepidopterous larvae: "There are a considerable number of setae which are constant in number and position in any given species." Although there are only two sets of setae on the labrum of the larva in many moth species, $\mathrm{L}_{1}-\mathrm{L}_{3}$ and $\mathrm{M}_{1}-\mathrm{M}_{3}$ (sensu Heinrich), some sphingid larvae may have additional setae; e.g., the additional pairs illustrated by Bell and Scott (1937: 8, fig. 2) for a species of Polyptychus. Additional pairs of setae (designated $\mathrm{X}_{1}-\mathrm{X}_{3}$ ) are therefore a significant character in demonstrating the relationships of the three species of Lapara.

Pupa (Fig. 9). The pupa is cylindrical. The tongue-case is probably concealed in all three species of Lapara, a character which separates the group from moths of the genus Sphinx. Apparently the only valid descriptions of the pupae of Lapara in the literature are those of Beutenmüller (1895) for $L$. coniferarum and $L$. bombycoides (L. harrisii). The pupa of halicarnie has not been described. Mosher (1918) worked specifically on sphingid pupae, but her conclusions regarding the pupae of Lapara are questionable. She studied material that was purchased and therefore of unconfirmed identification, a circumstance that may explain why she did not comment upon the very different shape of the cremaster in $L$. coniferarum and L. bombycoides.

\section{SYSTEMATIC POSITION OF LAPARA}

In colouring and size, the species of Lapara are similar to the east Asiatic species of the Sphingulini, a tribe created by Rothschild and Jordan (1903) for several genera including Kentrochrysalis and Sphingulus. Some of the anatomical features discussed above for the adults as well as the larvae and pupae also place Lapara near the Sphingulini.

When Rothschild and Jordan (1903: 154) separated the Sphingulini from the Sphingini, they distinguished the two tribes primarily on differences of the structure of the pretarsus and of the antenna in the adults, and the similarity of larvae and pupae of the former to those of the Ambulicinae (i.e., Smerinthini).

The structure of the pretarsus is important in the taxonomy of these moths. In their definition of the tribe Sphingini, Rothschild and Jordan (1903: 27) referred to this structure as follows: "Pulvillus and paronychium present or absent, the pulvillus disappearing before the paronychium, there being no species with pulvillus and without paronychium, the order in which these organs become obliterated being this: ventral lobes of paronychium, pulvillus, lateral lobes of paronychium." For the tribe Sphingulini, however, they noted (1903: 154) that all species have a pulvillus and that the paronychium is either with two lobes or absent. In addition they stated (1903: LXVIII) that "the paronychium of Sphingidae possesses in its most generalized state two slender lobes on each side, of which the upper (or lateral) lobe is generally the longer, very rarely the shorter one. The reduction of the paronychium begins with the ventral lobe; this is always the first to disappear, there being no hawk moths which possess the ventral lobe and are devoid of the lateral one. The remaining lobe becomes also gradually shortened, and disappears too." 
I found all three species of Lapara to have a pulvillus (greatly reduced in $L$. bombycoides) and a paronychium with only one (lateral) lobe (rudimentary in L. bombycoides, Fig. 5). The empodium is well-developed in all three species, especially in L. bombycoides, a surprising observation in light of Rothschild and Jordan's (1903: LXVIII ) statement: "The empodium is in Lepidoptera a small tubercle above the pad [pulvillus] between the claws, bearing one bristle, seldom two. It is widely distributed among the pad-bearing species, but is seldom found in Sphingidae (Sphingulus; Hopliocnema)."

In the discussion of certain genera of their Sphingulini, Rothschild and Jordan (1903: LXIX) said: “. . two closely allied genera Kentrochrysalis and Sphingulus. The former possesses a complete paronychium and a pulvillus; the latter genus has only a pulvillus. Here the paronychium has disappeared before the pulvillus. The intermediate stage between the two genera is not known; in this the paronychium would have one lobe." This latter description fits Lapara exactly, as would undoubtedly have been discovered by Rothschild and Jordan had they had sufficient material for the genus, especially $L$. halicarnie.

The structure of the third segment of the labial palpus of Lapara species indicates their closer relationship to the species of the tribe Sphingulini than to the species of the tribe Sphingini. Structure of the male genitalia also shows Lapara to have closer affinity with Kentrochrysalis and Sphingulus than with the Sphingini (particularly the genus Sphinx). Early authors (Butler, 1877; Martyn, 1797; J. E. Smith in Abbot and Smith, 1797; Strecker, 1880) placed Lapara species in Sphinx. But the clear distinction between the two genera is reinforced by the lack of a pulvillus in the latter. The larvae of Lapara are referred to by Koebele (1881) as "Smerinthus-like", an expression that Rothschild and Jordan (1903: 154) also used when they established the tribe Sphingulini. The pupae of Lapara described to date also correspond to the known pupae of the Sphingulini. However, the apical segment of the antenna in Lapara is similar to that in all genera belonging to the tribe Sphingini, where it was placed by Rothschild and Jordan (1903). The importance of this structure was noted by Bell and Scott (1937: 21), who remarked: "The end-segment is of particular taxonomic value. The length and shape, and the clothing with scales and bristles of this segment, vary very much and offer good distinguishing characters of genera and even tribes."

In the light of available evidence Lapara may be considered to be an evolutionary line intermediate between the Sphingini and Sphingulini, in many respects even nearer to the latter than to the former. However, because of their antennal structure, they should be left where they are, at the end of the Sphingini.

\section{PHYLOGENETIC RELATIONSHIPS OF SPECIES}

Two evolutionary lines can be distinguished in Lapara from larval and adult characters. One line is represented by L. halicarnie in which larvae have three pairs of X-setae on the labrum, and adults have the pulvillus well-developed and the paronychium with a single well-developed lateral lobe. Another distinct line is represented by $L$. coniferarum and $L$. bombycoides, in which larvae possess only two pairs of $\mathrm{X}$-setae (the derivative condition) and adults have the pulvillus 
poorly developed; in addition, the paronychium is short in coniferarum and minute in bombycoides. Thus, L. halicarnie would seem to be the most generalized and $L$. coniferarum and $L$. bombycoides the more specialized species of Lapara.

\section{BIOLOGY}

Although the species of Lapara are not rare, except perhaps L. halicarnie, they are nowhere abundant, and their natural history is poorly known. At northern latitudes populations are univoltine, especially in Canada. Farther south, perhaps south of New Jersey, a second generation, or at least a partial one, is likely. Koebele $(1881: 21)$ reported "at least 2 broods each year" for $L$. coniferarum in the southern United States. The size of populations of $L$. bombycoides, the only species for which data are available, appears to be stable with little fluctuation at localities in Ontario where the species has been collected for several years.

Adults fly at night from about 10:00 p.m. to approximately 4:00 a.m. in southern Ontario, but the pattern of activity probably varies in different parts of the range. In southern Ontario, L. bombycoides deposits eggs in mid-July. In $L$. bombycoides and L. coniferarum the eggs hatch in seven to ten days (Koebele, loc.cit.), and larval development takes about six weeks in both species. Larvae of all species normally feed on coniferous trees. An exception is a record of a caterpillar of $L$. coniferarum taken from Citrus sp. in Dade City, Florida (FSCA). To date no damage to economically important trees has been attributed to members of this genus.

Koebele (loc.cit.) recorded a characteristic behaviour for the protectively coloured larva of $L$. coniferarum. In the third and fourth instars when the head is most triangular (Fig. 8), if disturbed, the caterpillar thrusts its head ventrally so that it lies horizontally in a straight line with the body. Ordinarily the apex is carried erect. Larvae of $L$. bombycoides reared in our laboratory exhibited the same behavioural pattern when disturbed. The camouflage pattern of larvae of these two species is illustrated in Fig. 21d.

The larva pupates in the earth in a loose web and remains in the pupal state for a month (Koebele, loc.cit.) or more. 


\section{Key to Adults Based on External Features}

1. Apex of tegula with a prominent cluster of white hairs usually extending to the wing bases (Figs. 19c, 20c); basal area of fore wing heavily marked; single transverse brown band on underside of both wings usually well defined, particularly in males (Fig. 19d); length of fore wing in males $21-26 \mathrm{~mm}$ (52 specimens; 28 $\mathrm{mm}$ in one); length of fore wing in females $25-27$ mm (six specimens) . . . . . . . . . . . L. bombycoides Apex of tegula without white hairs (Figs. 19a-b, $20 \mathrm{a}-\mathrm{b})$; no heavy markings in basal area of fore wing . . . . . . . 2

2. Ground colour tawny; hind wing uniformly light tawny; longitudinal markings on fore wing often weak or absent (Figs. 19a, 20a); submarginal line indistinct, only suggested; no transverse bands on underside of wings; length of fore wing in males $29-36 \mathrm{~mm}$ (13 specimens); length of fore wing in females $32-40$ mm (six specimens) . . . . . . . . . . . . L. halicarnie

Ground colour brownish-ashy-grey; hind wing uniformly of this colour; postmedian longitudinal markings on fore wing usually well-developed (Figs. 19b, 20b); a thin, dark submarginal line connecting basal furcations of apical veins; transverse brown bands on underside of wings absent or, if present, only weakly developed; length of fore wing in males 24-30 $\mathrm{mm}$ (46 specimens), length of fore wing in females $27-36 \mathrm{~mm}$ (eight specimens). . . . . . . . L. coniferarum

\section{Key to Adults Based on Genitalic Features}

1. Males ........................... 2

Females ...................... 4

2. Process of sacculus slender and somewhat sinuate in ventral view (Figs. 11c, 12c) . . . . . . . . . . . . . 3

Process of sacculus short and curved, not sinuate, in ventral view (Fig. 13c) . . . . . . . . . . . . . . L. bombycoides

3. Mesal margin of process of sacculus strongly sinuate in ventral view, the base of the process averaging 0.37 mm wide (Fig. 11c) . . . . . . . . . . . . . . L. halicarnie

Mesal margin of process of sacculus weakly sinuate in ventral view, the base of the process narrower, averaging $0.24 \mathrm{~mm}$ wide (Fig. 12c) . . . . . . . . . L. coniferarum 
4. Anterolateral angles of vaginal plate extending into a deep concavity on each side of the lip between the seventh and eighth sternites, the surface of the concavity somewhat sclerotized and pigmented (Fig. 17a)

L. bombycoides

Anterolateral angles of vaginal plate extending into the lip between the seventh and eighth sternites, but without the prominent concavity described above

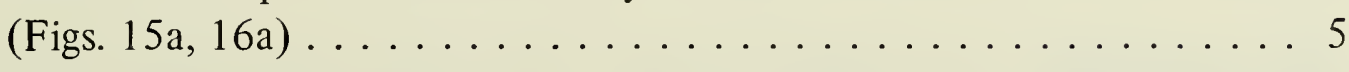

5. Ovipositor valves small; vaginal plate fairly evenly rounded throughout (Fig. 16a) . . . . . . . . . . L. coniferarum

Ovipositor valves large; lateral margin of vaginal plate with a distinct angle (Fig. 15a) . . . . . . . . . . L. halicarnie

\section{Key to Mature Larvae}

1. Body reddish-brown, with a regular, blackish, checkered pattern (Figs. 21a-b); labrum with three pairs of additional setae, $X_{1}-X_{2}-X_{3}$ (Fig. $\left.7 a\right) \ldots \ldots \ldots$. halicarnie Body green, labrum with two pairs of additional setae,

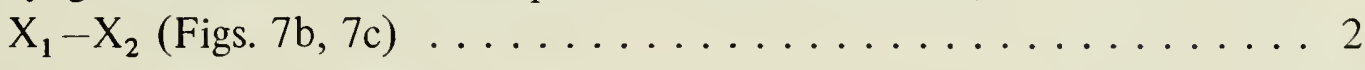

2. Body light yellowish-green, with an unbroken cherryreddish median dorsal stripe between the dorsal lines from thoracic segment II (occasionally III) to abdominal segment eight (Fig. 21c); ventral surface broadly suffused with a cherry-reddish coloration; head capsule rounded dorsolaterally in frontal view (Fig. 6b) L. coniferarum

Body pine-needle green, with either an unbroken reddish-brown median dorsal stripe from thoracic segment III to abdominal segment eight, with only splashes of colour on the most posterior segments, or with colouring absent (Fig. 21d); ventral coloration condensed into a pinkish stripe, commencing at the third pair of legs, widening as it proceeds caudally, and embracing the prolegs; head capsule less rounded dorsolaterally, tending to be angular in frontal view (Fig. 6c) 


\section{Lapara halicarnie (Strecker)}

Sphinx halicarnie Strecker, 1880, p. 35, fig.; Strecker (1872 ss.) 1900, p. 26.

Exedrium halicarnie: Grote, 1882, p. 11; J. B. Smith, 1888, p. 211.

Exedrium halicarniae: J. B. Smith, 1888, p. 240; Kirby, 1892, p. 696.

Lapara halicarniae: Rothschild \& Jordan, 1903, p. 153; Wagner, 1913, p. 73;

B. P. Clark, 1919, p. 102, pl. XI, fig. 1, pl. XIII, fig. 1; Draudt, 1931, p. 860, pl. $95 \mathrm{~d}$.

The orthography of the specific name as used in the few instances where the species has been mentioned in the literature since 1888 is incorrect. J. B. Smith (1888) introduced the misspelling in the list of the Sphingidae of temperate North America at the end of his systematic monograph. As a Latin word "halicarnia" does not exist. A genitive ending in "ae" cannot be formed. Thus, another explanation of Strecker's "halicarnie" is needed. A perusal of other names Strecker applied to species reveals his preference for feminine proper names. This is especially true in the paper containing the original description of "halicarnie." In this original description Strecker said: "This Sphinx, of which I append a figure in order to exhibit the great breadth of primaries, is without doubt the most remarkable species yet discovered in this country." No wonder, then, that he chose the female proper name "Halicarnie", probably derived (with some linguistic acrobatics) from Halicarnasse, one of the seven wonders of the ancient world.

For a considerable period of time, it was thought that Strecker's type, a hypertrophic female now in the collection of the Field Museum of Natural History, was the only existing representative of the species. Although Rothschild and Jordan (1903: 153) acknowledged the existence of a single specimen, their description of coniferarum, as well as that by J. B. Smith (1888: 210) and others for this species, suggests that they had before them a mixed series that also included halicarnie (see p. 13).

Knowledge of the species halicarnie was greatly enhanced when Clark (1919), an avid collector of world sphingids, recognized that the type specimen was an abnormal female of that species. His material, six males and eight females, is preserved in his collection, which has been deposited in the Carnegie Museum. Now at least a few representatives of this species are in collections in many of the larger North American museums.

Adult. Clark (1919) compared halicarnie (Figs. 19a o, 20a \&) with coniferarum and stated: "It [i.e. halicarnie] is a much larger insect. The markings of the fore-wing are fainter, and of ten so vestigial that the wing is unicolourous, lacking even the two longitudinal postcellular dashes. These differences become very evident as one compares series of the two forms [i.e., species]. The genitalia are entirely different." To this description now may be added the following: fringes of the wings exhibiting almost no evidence of a checkered pattern; underside of wings without transverse brown bands. Representatives of the species are shown in Figs. 19a and 20a. Coloured reproductions of the hypertrophic female type and that of a normal female can be found in a publication by B. P. Clark 
(1919, pl. XIII, fig. 1; pl. XI, fig. 1). The figure given by Draudt (1931, pl. 95d) is a replica of Clark's original illustration.

The third segment of the male labial palpus (Fig. 3a) is short and broad, with both sides convexly rounded; in the female it is long and slender, with almost straight sides. As mentioned before, this kind of sexual dimorphism occurs only in L. halicarnie.

The epiphysis (Fig. 4a) is massive, elongate, with a wide furrow, and nearly closed at the tip.

Male genitalia (Fig. 11a-d): valve large and triangular, the apex attenuate. Process of sacculus (Figs. 11b, 11c) slender and sigmoidal; a thorn-like projection near the middle of the process; apical third covered with small, thorn-like spines; average width of process at its base $0.37 \mathrm{~mm}$. Aedoeagus (Fig. 11d) drawn out caudally into a bent, pointed process; vesica with two somewhat cone-shaped projections; uncus-gnathos chelate in lateral aspect, not heavily sclerotized.

Female genitalia (Fig. 15a-b): ovipositor valves large, rounded (Fig. 15b, lateral view). Vaginal plate chevron-shaped, with lateral margins distinctly angulate. A narrow rectangular sclerotized plate situated at about the level of the ostium bursae in the membranous band that goes around the ostial area from end to end of the vaginal plate. Ratio of postapophyses: antapophyses, 1:0.84. Ductus bursae tube-like, turning dorsally at three-quarters of its length, with thick walls imparting a doubled appearance. Ductus seminalis arising at a point approximately one-quarter of length from distal end. Corpus bursae globular or oblong, surface heavily marked with grooves.

Larva (Figs. 6a, 7a, 21a-b). A brown, dorsally checkered caterpillar was described and figured by J. E. Smith in Abbot and Smith (1797, plate X LII) under the specific name coniferarum. But the identity of the specimen illustrated and its relationship to the adult figured have been doubted. Boisduval (1874: 105) noted the dissimilarity between the specimen of this figure and other illustrations of presumed coniferarum that he received from Abbot, the delineator of the illustrations in Abbot and Smith (1797). Because he questioned the validity of the caterpillar described in Abbot and Smith, Boisduval described another caterpillar as coniferarum, based on Abbot's additional drawings.

Further mention is made of the checkered caterpillar (sensu J. E. Smith in Abbot and Smith) by Strecker (1874: 93), Fernald (1886: 85), J. B. Smith (1888: 211), and Packard (1890: 768), the last three in reference to reports by Koebele (1881) of a parasitized caterpillar taken in Tallahassee, Florida. Beutenmüller (1895) and others subsequently demonstrated that the immature stage described by Boisduval was indeed that of coniferarum. However, the identity of J. E. Smith's caterpillar remained to be determined. Forbes (1948: 192) stated that the colour pattern, "dull brown and checkered with unusual regularity", was diagnostic of the species halicarnie, and his description agrees with the figure published by Abbot and Smith (1797). Thus, the source of confusion in the earlier literature was the incorrect association of the halicarnie caterpillar with an adult coniferarum by J. E. Smith.

The figure of the caterpillar published in the work of Abbot and Smith (1797) as the larva of coniferarum agrees with characters of two inflated cater- 
pillars without locality data in the collection of the Carnegie Museum. The description of these caterpillars follows: head moderately triangular (Fig. 6a); frons reddish-brown, bordered by a blackish marking having the form of a leaf of the waterplant Sagittaria; anterior ends of marking extending about 5/6 of distance from vertex to lower edge of head capsule. This marking is bordered by yellowish stripes with a reddish-brown tinge; these stripes again bordered laterally by blackish stripes terminating shortly above the eyes; rest of head capsule reddish-brown, heavily sprinkled with blackish and yellowish granules; labrum (Fig. 7a) with setae $\mathrm{L}_{1}-\mathrm{L}_{3}, \mathrm{M}_{1}-\mathrm{M}_{3}$, and $\mathrm{X}_{1}-\mathrm{X}_{3}$.

Body reddish-brown "checkered with unusual regularity" (Forbes, 1948: 192) (Figs. 21a-b); entire body sprinkled with conspicuous small brownish warts on yellowish dots. Pronotum patterned differently from rest of body; as on the head capsule, heavily granulated with blackish tubercles; marked with a narrow, yellowish mid-dorsal line and with a pair of sub-median and a pair of dorso-lateral blackish lines. Remainder of body segments with a complex marking composed of a continuous, narrow, yellowish mid-dorsal line, flanked on either side by several yellowish sub-median and dorso-lateral longitudinal bands of various widths; these bands regularly interrupted by blackish patches of various intensities, which are staggered in alternate bands creating the unique checker-board effect. In the inflated specimen, illustrated in Fig. 21a, some of the integument has stretched and colours have faded so that the over-all pattern has been partially obliterated. However, if Fig. 21a is compared with a copy (Fig. 21b) of the illustration in Abbot and Smith (1797), the elements of the pattern can be distinguished. Anal segment with only remnants of the different lines and patches; without caudal horn.

Pupa. Pupae of this species could not be obtained for study, and this stage has not been described in the literature.

Type material. The type of L. halicarnie, a female in good condition, is in Strecker's collection in the Field Museum of Natural History, Chicago. The specimen was taken in Florida in the summer of 1878 by the Reverend George D. Hulst.

Distribution. L. halicarnie is restricted to the south-eastern portion of the United States, with records from Florida, Georgia, South Carolina, and North Carolina.

Material Examined. Specimens examined were from the following localities and collections: UNITED STATES. America Borealis: no other data (CM). Florida: no other data (FMNH-type, AMNH, CM, FMNH, ROM); central Florida (CM); Archbold Biological Station (DCF, JGF, YPM); Cassadaga (FSCA); Charlotte Harbor (AMNH, CM); Coral Gables (WES); De Land (FMNH); Enterprise (CM); Florida City (AMNH); Ft. Meade (USNM not seen); Gainesville (FSCA); Miami (AMNH, CM, WES); Port Sewell (AMNH); St. Petersburg (USNM not seen). Georgia: Nashville (FMNH); Waycross (FMNH). North Carolina: Southern Pines (CM). South Carolina: Charleston (USNM not seen). 
The material consisted of 25 males and 23 females of which five males and six females were dissected. There are probably two generations, with the first flight period from early January to late April and the second from mid-June to mid-August.

\section{Lapara coniferarum (J. E. Smith)}

Sphinx coniferarum: J. E. Smith in Abbot and Smith, 1797, p. 83, t. 42; Harris, 1839 , p. 297 , n. 10; Clemens, 1859, p. 174; Strecker, 1874, p. 93; idem, 1876, p. 116 , pl. XIII, fig. $15\left({ }^{*}\right)$.

Hyloicus coniferarum: Hübner, 1822, p. 139.

Anceryx coniferarum: Walker, 1856, p. 224.

Ellema coniferarum: Grote, 1873, p. 27; Butler, 1877, p. 626; Packard, 1890, p. 768; Fernald, 1886, p. 84; J. B. Smith, 1888, p. 210.

Lapara coniferarum: Grote, 1875, p. 228, n. 72; Beutenmüller, 1895, p. 310, pl. VII, fig. 1; Rothschild and Jordan, 1903, p. 150; Holland, 1903, p. 53, pl. III, fig. 16 (\$); Wagner, 1913, p. 71; Draudt, 1931, p. 860, pl. 95c; Forbes, 1948, p. 192.

Sphinx cana Martyn, 1797, pl. XIX, fig. 46-synonymy established Butler, 1877, p. 626 (Ellema).

The descriptions of L. coniferarum by Rothschild and Jordan (1903), Fernald (1886), J. B. Smith (1888), and others were not based only on this species but apparently were derived from mixed series of $L$. halicarnie and coniferarum. Certain descriptive passages raise doubts as to the homogeneity of the series studied by these authors. For example: "Variable in the distinctness of the markings of the forewing and in size. The transverse lines disappear sometimes, the discal streaks become faint in many specimens and the second is often absent" (Rothschild and Jordan, 1903: 151). A re-evaluation of the material, based on the morphological and anatomical features used here, indicates that intra-specific variation is not as great as was previously assumed. Moreover, the markings of the male often have a tendency towards greater expression, whereas in females there is a tendency towards less accentuated markings.

Adult. Ground colour of adults (Figs. 19b o, 20b $q$ ) brownish-ashy-grey, the postmedian dashes usually well-developed. Veins of anterior wing only slightly suffused with brownish-grey and terminating apically as inconspicuous dots; fringes of wings thus appearing only slightly checkered. Transverse brown bands on underside of wings absent, or occasionally weakly developed. Tegula without a cluster of white hairs at apex. Good colour reproductions are found in the works of Strecker (1876, pl. XIII, fig. 15) and Draudt (1931, pl. 95c).

The third segment of the labial palpus (Fig. 3b) has almost straight sides and narrows considerably towards the articulation with the second segment.

The epiphysis (Fig. 4b) is slender and elongate, with only a narrow furrow.

Male genitalia (Figs. 12a-d): valve (Fig. 12a) small and typically ovate, occasionally somewhat triangular. Process of sacculus (Fig. 12b, c) strongly sinuate in ventral view; usually a small thorn-like projection near the base of the 
process, sometimes more strongly developed (Fig. 12, inset); apical third with small thorn-like teeth laterally, rarely large (see Fig. 12, inset). The figure of the process of the sacculus by Rothschild and Jordan (1903, pl. XXXIX, fig. 12) illustrates the characteristics of a normal specimen of $L$. coniferarum. Average width of process of sacculus at its base is $0.24 \mathrm{~mm}$. Aedoeagus (Fig. 12d) similar to that of L. halicarnie; some filaments midway along length; cornuti absent; coecum oval. Uncus-gnathos as in L. halicarnie but not as heavily sclerotized and slightly more rounded.

Female genitalia (Figs. 16a, b): ovipositor valves small and somewhat pointed (Fig. 16b, lateral view). Sterigmal area heavily sclerotized but not so heavy as in L. halicarnie. Vaginal plate fairly evenly rounded throughout. As in L. halicarnie, a rectangular, lightly sclerotized plate occurs opposite the ostium bursae in the membranous band joining the ends of the vaginal plate around the ostium bursae. Ratio of postapophysis:antapophysis, 1:1.05. Ductus bursae tubular, the walls moderately thick. Ductus seminalis arising at end of posterior third of the ductus bursae. Corpus bursae oblong, marked with shallow grooves.

Larva (Figs. 6b, 7b, 8, 21c). Boisduval (1875: 105) who noted the discrepancies between the figure published by Abbot and Smith (1797, t. 42) and those of other illustrations prepared by Abbot for Boisduval as the larva of $L$. coniferarum, subsequently described a non-checkered caterpillar as that of coniferarum, an association that has since been verified by many authors (see discussion under Larva of L. halicarnie). As was discussed previously, the checkered caterpillar pictured by Abbot and Smith (1797) and mentioned by Koebele (1881) and others, is that of $L$. halicarnie, not of coniferarum. In addition, Forbes (1948: 192) stated: "Larva of coniferarum tending to have more red [than bombycoides], often with a continuous red dorsal area and heavy shading both sides of the white substigmal stripes."

Koebele (1881), who reared $L$. coniferarum, described the immature stages as follows: ". . .light yellowish-green in color with three white lines on each sideone just below the dorsal line-a second stigmatal-and the third half way between these. The back stigmatal spaces and the under part of the body are strongly marked with red. The body is cylindrical, hardly varying in size from one end to the other. There is no caudal horn through all its history. The head is of medium size, light yellowish-green, edged along the collar with a blue line. There is a black line running from each corner of the mouth to the summit of the head and there they meet one another. The head is rounded, somewhat conical, flattened in front. The length of the full grown larva is $2-3 / 4$ to 3 inches [10.8-11.8 $\mathrm{cm}]$. - The egg is very dark green and hatches in 8 days. . . The pink color occurs in the larva only after the third moult. - The most remarkable part of the history of the insect is the extraordinary change which takes place in the shape of the head of the larva at different periods of its growth. Immediately after birth it is round. With the first moult it becomes angular and Smerinthus-like. This is very much increased with the second and third moults so that in these it is fully 4 or 5 times its width running up to a sharp point at the summit. When disturbed at this age the larva thrusts down the extremity of its head so it lies straight in a line with the body. Ordinarily it carries the point erect." The head of the immature caterpillar is shown in Fig. 8. 
The following additions to the description of the caterpillar of $L$. coniferarum are based on four inflated caterpillars and four preserved in alcohol. The inflated specimens, without locality data, are in the collections of the American Museum of Natural History and the Carnegie Museum. Those preserved in alcohol are from the collection of the Florida State Collection of Arthropods-two from Perry, one from Dade City, and one from Sanford, Florida; the foodplants were given as Pinus longifolia, Pinus taeda and Citrus sp., respectively. Abbot and Smith (1797) also mentioned cypress as a foodplant.

Head (Fig. 6b) of the mature larva slightly triangular; frons cherry-reddish, bordered by black stripes fading out anteriorly; light yellow stripes between the latter and the yellowish-green (body colour) remaining areas of the head capsule; frontal plate somewhat shorter and wider than in bombycoides; labrum with setae $L_{1}-L_{3}, M_{1}-M_{3}$ and only $X_{1}$ and $X_{2}$ (Fig. $7 b$ ) forming a concave line; pronotum and head capsule bearing yellowish granules; on thoracic segment II (sometimes also III) a cherry-reddish spot in place of the spiracle; spiracles on the abdominal segments have anteriorly and posteriorly a cherry-reddish smear increasing in size caudally, filling the entire segmental space above the creamywhite unbroken infraspiracular line in abdominal segment 8; the paired dorsal and lateral stripes creamy-yellowish in colour; thoracic segment II (or III), abdominal segments $1-8$, and anal segment with a cherry-reddish patch between the dorsal stripes; anal plate covered with small spinules, unicolourous, greenishor cherry-reddish, bordered by yellow; cherry-reddish splashes ventral to the infraspiracular line beginning on thoracic segment II (or posteriorly) to abdominal segment 8; abdomen broadly suffused ventrally with cherry-reddish colouring that also covers the semicoronate prolegs and the anal segment with the anal legs; the entire body of the larva sprinkled with yellowish dots, more distinct on the ventral surface, and with small spinules, especially dorsally. No caudal horn.

Pupa. Pupae were not available for this study. Beutenmüller (1895), however, described the pupa as: "Cylindrical, pitchy black. Head, thorax, and anterior margin of wing-covers rugosely punctate as are also the fore margins of the segments. The four posterior segments are rugosely punctate nearly over their entire surface. Anal spine pointed. Tongue-case concealed. Length, $32 \mathrm{~mm}$." The applicability of Mosher's (1918) description of the pupa of this species is doubtful, because she used purchased material whose authenticity she suspected herself.

Type material. It has not been possible to locate type specimens of either $L$. coniferarum or L. cana. Clemens (1859: 174) based his description on "Abbot \& Smith's figure". Butler (1877: 626) did not mention any type of coniferarum or cana in the British Museum (Natural History), although he treated all types kept in that institution. A. H. Hayes, British Museum (Natural History), stated (in litt.) that no specimens of Lapara that could have served as the basis for illustrations of coniferarum or cana could be located in the British Museum collection.

The type material is therefore considered to be lost; only the illustrations are available. 
It seemed, however, to be neither necessary nor opportune to assign a neotype in this case.

Distribution. L. coniferarum is sympatric with $L$. bombycoides over much of its range and is also sympatric with $L$. halicarnie wherever the latter occurs. The distribution of this species includes the following states and provinces: Florida, Alabama, Mississippi, Tennessee, Georgia, South Carolina, North Carolina, Virginia, Maryland, New Jersey, Pennsylvania, New York, Rhode Island, and possibly Nova Scotia.

In the Carnegie Museum collection are two specimens of $L$. coniferarum with the locality given as "Nova Scotia". If valid, these are the northernmost and also the only known records for this species from Canada. D. C. Ferguson (now of the United States Department of Agriculture, Washington, D.C.), who worked for many years in Nova Scotia, remarked (in litt.): "Coniferarum seems to be associated exclusively with the so-called hard pines, species such as $P$. rigida and virginia, and not with White Pine. It is possible that the Nova Scotian coniferarum that you spoke of were taken in an area of Jack Pine, which is closely related to Pinus rigida. Jack Pine is limited mostly to Cumberland and Colchester Counties in Nova Scotia, and I never managed to collect any Lapara in these areas." The specimens in question belong to B. P. Clark's collection and were obtained by him from a dealer in Brooklyn, New York.

Material Examined. Specimens examined were from the following localities and collections: CANADA. Nova Scotia: no other data (CM). UNITED STATES. Alabama: Cottondale (R OM); Loxley (AMN H); Shoal Creek Ford, $10 \mathrm{~km} \mathrm{NNW}$ Edwardsville (MSU); Wilmer (WES). Connecticut: no other data (CM). Florida: no other data (AMNH, CM, FMNH, MSU); central Florida (CM); Alachua Co. (FSCA); Altamonte (MCZ); Archbold Biological Station (DCF, Y PM); Cassadaga (FSCA); Coral Gables (CM); Dade City (larva FSCA); Fernandina (AMNH); Florida City (JGF); Ft. Walton (FMNH); Gainesville (AMNH, FSCA); Hilliard (AMNH); Levy Co. (FSCA); Ocean City (FSCA); Orlando (WES); Perry (larva FSCA); Quincy (AMNH); St. Petersburg (AMNH); Sanford (larva FSCA); Shalimar (FSCA); Tallahassee (AMNH, FSCA); Tampa (CM); Titusville (CM). Georgia: Baldwin (ROM); Emory Univ. (FSCA); Thomasville (CM). Maryland: Baltimore (CM, FMNH, ROM); Chevy Chase (MCZ). Massachusetts: Weston (MCZ). Mississippi: Biloxi (AMNH, YPM, ROM, WES); Brooklyn (FSCA); Camp Shelby (AMNH); Clear Spring Recreation Area nr. Meadville (MSU); Carnes (WES); Clinton (ROM); Hattiesburg (AMNH, ROM); Jackson (AMNH, ROM, WES); nr. Meadville (MSU); Pearl (ROM); Tape Co. (ROM). New Jersey: Clementon (CM); Edgewater Hts. (AMNH); Lakehurst (AMNH, CM, CNC, DCF, MCZ, ROM, WES); Manahawkin (AMNH, ROM); Ocean Co. (AMNH); Wrangle Brook Rd. (AMNH, DCF, ROM). New York: no other data (CM); Bedford (ROM); Coram, L. I. (CM); Hudson (CM); Leeds (CM); New Windsor (CM); New York City and vicinity (AMNH); Sull Co. (CM); Yaphank, L. I. (CNC). North Carolina: Charlotte (AMNH); Cherry Point (YPM); Fontana (CM); Sylva (FMnH); Wilmington (YPM). Ohio: Hocking Co. (OSM). Pennsylvania: Lititz (FMNH); Pittsburgh (WES); Williamsport (CNC). Rhode Island: Lonsdale 
(FMnH); Rockland (ROM). South Carolina: Clemson (Clu); Coosawhatchie (AMNH); Florence (CLU); McClellanville (ROM); Myrtle Beach (WES); Ridgeland (ROM). Tennessee: Great Smoky Mt. Nat. Park, Gatlinburg (MSU-the only melanic specimen); Johnson City (AMNH). Virginia: Amherst (CM); Arlington (JGF); Clarksville (WES).

The material consisted of 192 males and 49 females, of which 41 males and 13 females were dissected. In the southern part of the range (Florida, Mississippi, Carolinas, Georgia), there are two distinct flight periods, one from late March to early May and another from early June to mid-September; in the central area of the range (New Jersey, Maryland, Massachusetts) there is a single period, from the beginning of May to mid-August (probably representing two overlapping generations); and in the northern part of the range (New York, Connecticut, Pennsylvania) a single flight period occurs from mid-June to September, probably representing one primary and a partial second generation.

\section{Lapara bombycoides Walker}

Lapara bombycoides: Walker, 1856, p. 233; Clemens, 1859, p. 187; Butler, 1877 , p. 626; Strecker, 1877, p. 127, pl. XIV, fig. 7 (Lipara!); Rothschild \& Jordan, 1903, p. 152, pl. XXVIII, fig. 21, pl. XXXIX, fig. 13; Holland, 1903, p. 53, pl. III, fig. 7; Wagner, 1913, p. 72; Draudt, 1931, p. 860, pl. 95d; Forbes, 1948, p. 192.

Ellema bombycoides: Fernald, 1886, p. 82; J. B. Smith, 1888, p. 208.

Ellema harrisii: Clemens, 1859, p. 188; Walker, 1864, p. 37 (Eilema!); Bethune, 1868 , p. 18; Lintner, 1872, p. 170, pl. 8, figs. 8, 9, 10, 11; Boisduval, 1875, p. 106 (Sphinx); Strecker, 1876, p. 116, pl. XIII, fig. 16 (Sphinx); Butler, 1877, p. 626; ibid. p. 642 (Hyloicus); Packard, 1890, p. 768, figs. 264 a, b, 265 a, b, pl. XI, fig. 5, pl.XXXIV, fig. 1 a-j (larval details); Fernald, 1886, p. 83 (bombycoides var.); J. B. Smith, 1888, p. 207; Beutenmüller, 1895, p. 310, pl. VII, fig. 2 (Lapara bombycoides var.) -synonymy established Grote, 1875, p. 228, no. 73, and others, latest Rothschild \& Jordan, 1903, p. 152.

Adult (Fig. 19c, d o, 20c $\$$ ). Most with distinct brown ante- and postmedian transverse bands and postcellular dashes, giving a warm-brown, somewhat checkered appearance; the light, serrate, postmedian transverse band occluded apically by a brown arcuate band; a brown patch on the inner margin of the fore wing; the veins of the fore wing suffused with brown, terminating at the wing margin in distinct brown dots; fringes strongly checkered.

Geographic variation in colour is pronounced in this species. In the New Jersey population and in the more southern populations, the predominantly brown colour is muted by a lead-grey tone. Throughout the entire range, except for southern areas, specimens are found that individually tend to be suffused with brown, often to the extent of obliterating almost all markings. In the central portion of the range, specimens occur which exhibit more accentuated markings and a somewhat lighter shade of brown. These latter were described by Clemens (1859) as a distinct species (sui iuris), under the name of Ellema harrisii, with the type locality given as Brunswick, Maine. Grote (1875) synony- 
mized harrisii without further explanation. Rothschild and Jordan (1903: 152), who compared the type of bombycoides in Oxford with specimens of harrisii, found no difference between the taxa and synonymized them. The concordance of the genitalic structures, the shape of the head and the structure of the epiphysis of the legs, as well as similarities of the caterpillars (see Larva), are further evidence in support of the argument that harrisii is a synonym of bombycoides.

Despite the variation in coloration, bombycoides can usually be distinguished from coniferarum and halicarnie by the presence of prominent transverse bands on the underside of the wings (Fig. 19d) and by the unique cluster of white hairs at the apex of the mesothoracic tegulae, which are particularly conspicuous in infra-red photographs.

The third segment of the labial palpus (Fig. 3c) is distinctly convex on one side, on the other more nearly straight, and not narrowed basally.

The epiphysis (Fig. 4c) is characterized by one uniformly convex side, with the other almost entirely straight; the tip is not as pointed as in the other species, the furrow more extended.

The anterior pretarsus of the male is unique for the genus in having an empodium of two tubercles (Fig. 5b), each bearing a seta; tubercles much reduced and difficult to locate, setae very fine.

Male genitalia (Figs. 13a-d): valve small and oval (Fig. 13a). Process of sacculus (Figs. 13b, c) short and angled dorsally and mesally, not sinuate, consisting of two angulate rods fused near the apex, which is adorned with small teeth. Small, thorn-like process (frequently unilateral), often found at elbow formed by junction of arm and terminal process of sacculus. The figure published by Rothschild and Jordan (1903, pl. XXXIX, fig. 13) also illustrates the fusion of the rod-like structures in marked contrast with those of the other two species. Average width of process of sacculus at its base, $0.315 \mathrm{~mm}$.

Aedoeagus (Fig. 13d) similar to that of $L$. halicarnie and $L$. coniferarum but with slight differences in the vesica (cf. Figs. 11d, 12d); coecum slightly shorter and oblong to oval in shape; uncus-gnathos similar to that of $L$. halicarnie but more massive and slightly shorter when viewed laterally.

Female genitalia (Figs. 17a-b): structures remarkably different from those of $L$. halicarnie and $L$. coniferarum. Valves of ovipositor large and rounded (Fig. $17 \mathrm{~b}$, lateral view). Vaginal plate shaped like an arrowhead; lateral margins strongly rounded, anterolateral angles extending into a deep concavity on either side of the lip between the seventh and eighth sternites; surface of this concavity somewhat sclerotized and pigmented. Ratio of postapophysis: antapophysis, 1:0.77. Ductus bursae with posterior half swollen into a goblet-shaped structure, anterior half tubular, walls thick. Ductus seminalis arising near middle of ductus bursae, at base of posterior swelling; corpus bursae partially invaginated at end of ductus bursae.

Larva (Figs. 6c, 7c, 21d). Forbes (1948: 192) described the caterpillar of bombycoides: "Larva mostly green and white, at most with a red face and small red dorsal spots." This account is similar to the description presented for harrisii (Clemens), by Boisduval (1874: 106). His description included the following statements: "La chenille, comme celle du coniferarum, est dépourvue de corne 
sur le onzième segment. Elle est verte, un peu amincie aux extrémités avec un raie dorsale un peu interrompue en arrière, d'un brun-rougeâtre, et avec une raie latérale jaune et une bande sous-stigmale blanche; outre cela, ses pattes écailleuses sont roses ainsi qu'une raie ventrale." Lintner (1864), who was most familiar with Lapara caterpillars, described the caterpillar of "harrisii" as follows: "2 in. long [i.e. $7.8 \mathrm{~cm}$ ], .23 in. broad [i.e. $0.9 \mathrm{~cm}$ ]. Subcylindrical, tapering slightly anteriorly, and the last two segments quite tapering. Head, size of first segment, granulated, flattened anteriorly, sub-triangular, with an impressed medial line, and straight yellow lateral lines terminating at the apex in two black granulations, and bordered interiorly above with black. Body grassgreen. Subdorsal and lateral bands yellow. Substigmatal stripe bordering the stigmata, white, enlarged on the central portions of the segments. Between the subdorsal and substigmatal stripes,-on the fourth and fifth segments ventrally,and exteriorly to the legs and prolegs, dotted on the annulations with paler green or yellow. On the vascular line, a series of crimson spots on the anterior of the segment, commencing usually on the fourth,-the first small, sometimes doublethe anterior ones triangular or lozenge-shaped, regularly increasing in size and extending over more of the segment-the posterior ones quadrangular, and uniting on the last two segments in a stripe. A ventral stripe of rose-colour, commencing at the third pair of legs, widening as it proceeds, and embracing the prolegs. No caudal horn. Caudal shield granulated, and edged with white. Stigmata oval." (This description is re-printed here to give additional evidence from the caterpillar that "harrisii" is correctly a synonym of bombycoides.) Detailed illustrations of the caterpillar of bombycoides are found in the work of Packard (1890), p. 769, pl. XI, fig. 5, and pl. XXXIV (mistakenly listed under coniferarum on text p. 768).

The following description of the immature stages of bombycoides is based on living material reared from eggs of two females taken at Kendal, Ontario, 11 July 1967 and on two inflated caterpillars and one preserved in alcohol. The inflated caterpillars (from the collection of $\mathrm{AMNH}$ ) are without locality data. The one preserved in alcohol, from Perry, Florida, is in the Florida State Collection of Arthropods. Also used was a Kodachrome transparency taken by A. B. Klots (AMNH) of a mature bombycoides caterpillar from Putnam, Connecticut.

The egg is elliptical, of a greenish-yellow pastel colour with the surface finely chiselled. About 9 days are required for it to hatch.

Caterpillar in last instar about $50 \mathrm{~mm}$ long; body pine-needle green, wellcamouflaged by the presence of equally spaced creamy-white, unbroken dorsal and lateral stripes that are comparable to the white stripes of the pine needles. Head (Fig. 6c) of the mature caterpillar more triangular and pointed than in coniferarum; frons light purplish-pinkish, bordered by dark brownish-red stripes that fade out anteriorly; these bordered by bright yellow stripes; rest of head capsule of the same green colour as the body; frontal plate more elongate and narrower than in coniferarum; labrum with setae $\mathrm{L}_{1}-\mathrm{L}_{3}, \mathrm{M}_{1}-\mathrm{M}_{3}$ and only $\mathrm{X}_{1}$ and $\mathrm{X}_{2}$ (Fig. 7c); X-setae forming a convex line; head capsule more granulate than in coniferarum; pronotum as the head capsule, densely covered with fine yellow granulations. Spiracles on abdominal segments surrounded by a slight tinge of purplish-pink; infraspiracular line pure white (unbroken on thoracic 
segment I to abdominal segment 1, interrupted at intersegmental boundaries, rounded on abdominal segments 2 to 8 , and absent on anal segment), wider than other longitudinal lines. On the anal segment occur only lateral lines. In the reared caterpillars (Fig. 21d) the space between the dorsal lines is completely filled with purplish reddish-brown from thoracic segment III to the anal segment, whereas thoracic segment II shows only a little colouring. The specimen photographed by A. B. Klots has some colouring but only on abdominal segments 6 to 8 and the anal segment. The inflated caterpillars have an intermediate colouring. The abdomen ventrally with not more than a purplish-pink, relatively broad median line, with lateral connections to the semicoronate prolegs and anal legs; the entire body of the caterpillar sprinkled with yellowish dots and with minute spinules, but not as heavily as in coniferarum and spinules smaller. The first signs of dorsal colouring appear in some caterpillars by the fourth instar.

Known foodplants (see McGugan, 1958) are Pinus banksiana, $P$. resinosa, $P$. rigida, $P$. strobus (in the eastern provinces and states and in southern Ontario), and Larix laricina. $P$. taeda is the foodplant given for the specimen from Perry, Florida.

Pupa (Fig. 9, pupa of Fig. 21d). Beutenmüller (1895) wrote: "Chestnut brown, with a rough, not produced head-case. Tongue-case buried. Posterior segment tapering. Terminal spine black, contracted at base, minutely bifid at tip. Length, ...[25-27 mm]." This description agrees with a pupa (Fig. 9) from the ROM collection reared from the eggs of females taken at Kendal, Ontario, in 1967. It should be noted that the bifurcation of the terminal spine is so fine that it appears as a "tuning fork" only in the very recently formed pupa. Usually only the two basal stumps remain in older pupae. Lintner (1864) described the pupa in the same way as Beutenmüller.

Type material. According to Strecker (1877), Fernald (1886), and Rothschild and Jordan (1903), the type of L. bombycoides is in the Museum at Oxford, England, specifically in the Hope collection of Oxford University (Strecker, 1877). Strecker (1877) published "an accurate coloured figure of the type" that was made for him by Prof. Westwood in 1875. It appears to be a female.

In his description Walker (1856) gave the type locality as "Canada. In Mr. Saunder's collection." As Strecker (1877) said, the type was then unique.

Where the type of harrisil is deposited is unknown. Clemens (1859) says after his description: "From the collection of Mr. A. S. Packard Jr., Brunswick, Me." In his special study of Clemens' types, Darlington (1947) said: "Lapara harrisii (=bombycoides Walker), p. 188. Type not located. Described from a specimen in A. S. Packard's collection."

In connection with these remarks about type material of bombycoides, the question of the creation of a synonym by Harris must be resolved. In 1839 Harris published his catalogue of the North American Sphinx and listed on p. 297, under no. 10, "S. Coniferarum. Smith-Abbot." His description agrees well with that of the insect originally described by J. E. Smith in Abbot and Smith in 1797. It would appear that Harris did not intend to describe any new and 
hitherto unknown insect, for he placed the authors' names after the specific name and as well referred to the caterpillar pictured by Abbot and Smith.

On the other hand, it seems equally clear from the second paragraph of his note (p. 297), that Harris' own specimen, the specimen "in the Cabinet of T.W.H.", probably was not $L$. coniferarum, because this species, as far as is known, does not occur in Vermont. The small size of the specimen is probably not taxonomically important, because it was reared. Nevertheless, Harris mentioned that the specimen, taken in North Carolina and in the collection of the Boston Society of Natural History, was larger. This specimen is undoubtedly referable to L. coniferarum (J. E. Smith), for Harris' last words in his note were: "the bands on the wings in the latter are less distinct than in my specimen." The description clearly applies to this species.

Harris undoubtedly believed that the two specimens of Lapara represented a single taxon, when actually they were representatives of two distinct species. His own specimen was $L$. bombycoides, a new taxon that was described 16 years later by Walker (1856). Thus, the distinctiveness of his specimen was not detected by Harris and he consequently misidentified it (Bethune, 1868: 18). Even so, a misidentification is not a cause for synonymizing a name, and the synonymy of "Sphinx coniferarum Harris (non Smith and Abbot, 1797) (partim)" under bombycoides or harrisii, respectively, as was given by Clemens (1859), Morris (1862), J. B. Smith (1888), Rothschild and Jordan (1903), and Wagner (1913) is incorrect.

A final comment on the synonymy under L. bombycoides. In 1862 (p. 382) Harris published on the caterpillar of $S$. coniferarum, and Wagner (1913, pars 12 , p. 72) included Harris' short statement in his synonymy of bombycoides. Wagner's action was not only incorrect but also inappropriate, for Harris clearly referred to the caterpillar pictured by Abbot and Smith (1797) on plate XLII.

Distribution. L. bombycoides, the most common of the three species of Lapara, is widely distributed in Canada and the United States from the Atlantic Coast south to Florida, and west to Saskatchewan, Nebraska, and British Columbia. In the central and southern portions of its range, it is sympatric with L. halicarnie, L. coniferarum, or both.

Records (including those from the literature) have been obtained for the following states and provinces: Florida, Georgia, North Carolina, Tennessee, Indiana, West Virginia, Maryland, Pennsylvania, New Jersey, New York, Connecticut, Rhode Island, Massachusetts, Vermont, New Hampshire, Maine, Nova Scotia, New Brunswick, Quebec, Ontario, Manitoba, Saskatchewan, British Columbia, Nebraska, Minnesota, Wisconsin, Michigan.

Kimball (1965: 61) questioned the occurrence of $L$. bombycoides in Florida and stated: "Certainly there is no clear-cut record of it here; in fact, the only one is 'Florida' (Rothschild and Jordan, 1903: 152). ..". The specimens referred to by Rothschild and Jordan are now housed in the collection of the British. Museum (Natural History) and were kindly sent on loan for this investigation. Both are males, with one bearing the label "Florida" and the other "Palm Beach, Florida." Neither specimen differs in any aspect from Ontario specimens, and the slight differences in the structure of the genitalia mentioned by Rothschild and Jordan are within the normal range of individual variation for this species. 
Moreover, there is a caterpillar of this species, taken 30 April 1959 at Perry, Florida, in the Florida State Collection of Arthropods in Gainesville. L. bombycoides obviously does occur in Florida, if only rarely.

Material Examined. Specimens examined were from the following localities and collections:

CANADA. Canada: no other data (AMNH). Manitoba: Red Rock Lake, Whiteshell Park (AMNH). New Brunswick: Bathurst (DCF); Caraquet (DCF); Fredericton (CNC). Nova Scotia: no other data (CM); Armdale (CNC, DCF); Aylesford (DCF); Baddeck (DCF); Brierly Brook (DCF); Lake Kejimkujik (AMNH, DCF); Petite Rivière (DCF); S. Milford (CNC); White Point Beach (AMNH, CNC). Ontario: no other data ( $\mathrm{CNC}$ ); Algonquin Prov. Park (ROM); Ancaster (CNC); Bainsville (LEM); Bancroft (CNC); Bertram I., Lake Nipissing (ROM); Biscotasing (CNC); Bracebridge (AMNH); Camden East (CNC); Camp Borden (ROM); Chaffeys Locks (ROM); Chapleau (ROM); Constance Bay (CNC); Dunnville (ROM); Franklin I., Georgian Bay (ROM); Geraldton (AMNH, ROM); Grand Bend (CNC); Gull Lake, Muskoka (AMNH, CNC); Kendal (ROM); Marmora (CNC); Morris I., Muskoka (ROM); Muskoka (ROM); Normandale (CNC); One Sided Lake (AMNH, CNC, ROM); Ottawa (CNC); Port Credit (ROM); Rouge Hill (CNC); Rouge River (CNC); Sudbury (AMNH, CNC, ROM, WES); 1000 Islands (CM); Toronto (ROM); Trenton (CNC, ROM). Québec: Alcove (CNC); Amos (CM); Forestville (CNC); Hudson (LEM); Kazabazua (CNC); Kingsmere (CNC); Meach Lake (CNC); Montréal (CM, LEM); Murray Bay (CM, LEM); Norway Bay ( $\mathrm{CNC})$; Oka (CM); Ste. Thérèse I. (CM), UNITED STATES. Connecticut: Putnam ( A мnн). Florida: no other data (Bм); Palm Beach (BM); Perry (larva FSCA). Georgia: Oglethorpe University Campus (not seen, mentioned by Knudson, 1954). Indiana: Dune State Park (FMNH); Miller (FMNH); Mineral Springs (FMNH). Maine: no other data (CM); Augusta (FMNH, WES); Bar Harbor (AMNH, FMNH); Biddeford (LEM, WES); Dixfield (AMNH); Enfield (AMNH); Harrison (AMNH); Hope (AMNH, WES); Jackman (WES); Kittery Point (MCZ); Lincoln (AMNH, DCF); Mattawamkeag (AMNH); Mt. Desert (AMNH); Norway (AMNH); Old Orchard (CM); Oquossoc (WES); Paris (CM); Passadumkeag (JGF); Tim Pond (WES). Massachusetts: no other data (CM, FMNH); Amherst (MSU); Barnstable (AMNH, FSCA); Beverly Farms ( $\mathrm{MCZ}$ ); Cohasset (AMNH); Dorchester (MCZ); Forest Hills (CM); Groton (AMNH); Lenox (AMNH); Marlborough (YPM); Martha's Vineyard (YPM); Middlesex Co. (CNC); Neville (MCZ); Tyngsbro (MCZ); Weston (MCZ); Winchendon (CM); Wollaston (MCZ). Michigan: Allegan (MSU); Cheboygan Co. (WES); Chippewa Co. (MSU); Colombianville (WES); East Lansing (MSU); Keweenan Park (MSU); Otsego Co. (ROM); Schoolcraft Co. (AMNH, MSU, WES); Tecon Lake (MSU). Minnesota: I tasca State Park (OSU). Nebraska: no other data (CM). New Hampshire: Franconia (A M NH); Hampton (WES); Jefferson (CM); Jefferson Notch (DCF); Portsmouth (Y PM); Squaw Lake (MCZ); Walpole (CM). New Jersey: Lakehurst (AMNH, CNC, WES); Manahawkin (AMNH, ROM); Morgan (CM); Ocean Co. (AMnh, CM); Paul Smith's (LEM); Sussex Co. (AMNH); Wrangle Brook Rd. (AMNH). New York: no other data (AMNH, CM, FMNH, $\mathrm{MCZ}$ ); Northern N.Y. (CM); Adirondacks (CM, FMNH); Albany (AMNH, CM, MSU); Albany Co. (CM); Ausable (LEM); Bear Mt. (AMNH); Bedford (AMNH); 
Bluff I. (CM); Clayton (Picton I.) (A MNH); Cornwall (CM); Dryden, Ringwood Reserve (JGF); Green Co. (FMNH); Hudson (CM); Ithaca (AMNH, CM, JGF); Jamestown (CM, FMNH); Leeds (CM); Orange Co. (A MNH); Promised Land, L.I. (CM); Saratoga (CM); Taughannock (Ithaca) (AMNH); Ulster Co. (CNC); Valcour (LEM); Wading River, L.l. (CM). North Carolina: Brevard (FMNH); Doughton Park (MSU); Fontana (CM); L. Junaluska (FSCA); Tryon (CM); Tsali Recreation Area, 10 km. NE Stecoah (MSU). Pennsylvania: Clearfield (CM); Shawville (CM). Rhode Island: Cranston (CM); N. Scituate (ROM). Tennessee: Crossville (ROM); Great Smoky Mt. Nat. Park, Gatlinburg (MSU). Vermont: Pomfret (CM). West Virginia: no other data (CM). Wisconsin: Argonne (WES); Bailey's Harbor (WES); Chippewa Falls (WES); Cumberland (CM); Hancock (WES); Hazelhurst (AMNH); L. Katherine (WES); Lost Lake (Vilas Co.) (AMNH); North Bay (WES); Sauk City (WES); Vilas Co., nr. Sayner (AMNH); Waussa (AMNH).

The material consists of 605 males and 44 females, of which 18 males and 3 females were dissected. A single flight period occurs from early June to early August. One record from September (Clearfield, Pennsylvania) suggests a partial second generation.

\section{Incertae sedis: Lapara pinea (Lintner)}

Ellema pineum Lintner, 1872, p. 169, p1. 8, figs. 12, 13; ibid. p. 192; Butler, 1877, p. 626; Packard, 1890, p. 770, fig. 266a, b; J. B. Smith, 1888, p. 209. Sphinx pinea: Boisduval, 1875, p. 107.

Lapara pineum (!): Grote, 1875, p. 228; Rothschild and Jordan, 1903, p. 151; Holland, 1903, p. 53; Wagner, 1913, p. 71; Draudt, 1931, p. 860 (coniferarum ssp.); Forbes, 1948, p. 192 (bombycoides var.).

Lapara bombycoides pinetum (!): Dyar, 1902, p. 70.

The adjectival form used with Lapara, a noun of female gender, must be pinea; Ellema, the genus to which it was originally assigned, is neuter.

The status of this insect has always been questioned. Rothschild and Jordan (1903) considered $L$. pinea tentatively as a species but reserved judgement as to its definitive rank by the provision that "the two specimens should be re-examined." Dyar (1902) considered it to be a subspecies of bombycoides, and Draudt (1931), a subspecies of coniferarum. For this review the morphology of the genitalia and other structures was examined.

Adult. The type specimens, a male and a female, were pictured by Lintner (1872) in the original description beside a male and a female of "Ellema harrisii" (=bombycoides). Lintner (1872) stated that: "The species is readily distinguished from E. harrisii (Plate 8, figs. 10, 0,11,, ) by the darker ground of its wings, the absence of the grey shades, and its much less distinct markings." $L$. pinea is known only from the type specimens, and no additional specimens referable to this taxon were found among the material that I examined. Two specimens in the Clark collection of sphingids in the Carnegie Museum, however, are labelled "Ellema pineum." One (Clark \#5697, locality given only as New 
York, collected by Bruce) bears the notation "fide J. B. Smith". The other (Clark \#5564) is from Baltimore, Maryland, taken in June, the year and the collector unknown.

The process of the sacculus of the male genitalia of both Clark specimens is identical to that of $L$. coniferarum indicating that they are nothing other than small specimens of this species. The base of the process in both is $0.22 \mathrm{~mm}$ wide. The process is in one piece, and there are no fused rods. Also, the epiphysis is that of a small L. coniferarum. The colour of both specimens is the ashy-greyishbrown colour characteristic of $L$. coniferarum. The absence of distinct markings on the wings is a result of the worn condition of the specimens. The shape of the head and third joint of the labial palpi furthermore identify both as $L$. coniferarum. With a wing measurement of $24 \mathrm{~mm}$, Clark 5697 is within the usual range for $L$. coniferarum. Clark 5564, with the wing only $23 \mathrm{~mm}$ long, is rather small but agrees with $L$. coniferarum in all other characters.

The two Lintner specimens (Fig. 20d, $q$ type) are among the smaller Lapara specimens examined ( $\delta$ type measures $21 \mathrm{~mm}$ from right fore wing apex to base; i $25 \mathrm{~mm}$ ); fore wings not heavily scaled, umber coloured, a little greyish dusting at the base and near the apex, along the terminal margin, and on the principal veins and their branches; within the cell is a subquadrangular dark-brown heavy spot (in the $\$ 4 \times 1.25 \mathrm{~mm}$ ) parallel to the costal margin, a feature which all species of Lapara lack; a shade of the same dark-brown colour at the middle of the costal margin and at the apex; distally, a lighter brown semicircular area from the middle of the costal margin to the middle of the inner margin; hind wings of the same umber colour but only about a third as dark as the fore wings, paler still at the base; fringes distinctly checkered; colour beneath uniformly medium umber and without lines as in L. coniferarum; tegulae of the same umber colour, with some greyish hairs laterally and fine (arcuate) white lines on mesal margins as in L. coniferarum; abdomen of the same general umber colouring. Epiphysis very small, its shape intermediate between that of $L$. coniferarum and $L$. bombycoides. Labrum as in $L$. coniferarum. Third joint of labial palpi intermediate between that of $L$. coniferarum and $L$. bombycoides.

Valve of male genitalia (Fig. 14a) similar to L. bombycoides; process of sacculus short, not sinuate, as in L. bombycoides, abruptly bent dorsally and bearing thorns and hooks suggestive of $L$. halicarnie or $L$. coniferarum; structure similar to that of $L$. bombycoides, with two short rod-like components fused distally at the apex; width at base $0.18 \mathrm{~mm}$; aedoeagus (Fig. 14b) similar to the other three species of Lapara but thinner.

The female genitalia (Fig. 18) of $L$. pinea are in most respects similar to those of $L$. bombycoides. Ovipositor valves small and somewhat pointed, as in $L$. coniferarum; shape of the vaginal plate as in $L$. halicarnie; anterior lateral margins somewhat angulate, more so on one side than on the other; the anterolateral angles of the vaginal plate extending into a deep concavity on each side of the lip as in $L$. bombycoides. Ductus bursae tube-like, posterior half lightly sclerotized, turning anterolaterally to the right shortly before its termination; bursa copulatrix connected dorsally and obliquely to the left; ductus seminalis arising as a rather strong tube shortly before middle of ductus bursae. Corpus bursae similar to L. bombycoides but not invaginated, connected as in L. coniferarum; not heavily marked with grooves; signum absent. 
Larva. The type specimens were reared from caterpillars by Lintner, who found them in September of the years 1858 and 1859 in Schoharie, New York. Lintner succinctly stated the principal difference between the pinea and "harrisii" (=bombycoides) caterpillars. The former exhibits as "its characteristic feature" a dorsal row of interrupted red squares, which, as we know now, are also found in some bombycoides caterpillars. In 1860 Lintner observed that "in those taken this year the dorsal squares are not visible", later, however, he discovered that the caterpillars taken in 1860 were those of "harrisii". He stated further that he was unable to find additional caterpillars of $L$. pinea.

Lintner's statement was somewhat misunderstood by Boisduval (1875), who said: "La chenille a une si grande ressemblance avec la chenille de Harrisii, que Mr. Lintner a confondu ensemble les premières qu'il a trouvées. Les deux espèces vivent a même époque sur le Pinus strobus, dans l'Etat de New-York." This statement gives the impression that Lintner had confused his first and only pinea caterpillars with others and did not know from which batch he obtained pinea and from which one "harrisii". This was not so, however, as the two groups of caterpillars were collected in different years and were recognized by Lintner as separate entities.

Lintner (1872) described the caterpillar of $L$. pinea as follows: "Length two inches [i.e. $7.9 \mathrm{~cm}$ ]. Colour, grass-green. Head subtriangular, green, bordered with bright yellow, within which at the apex is a $\bigwedge$ of black. Body subcylindrical, tapering at the extremities, and without caudal horn. Dorsally, a reddish-brown line interrupted on the hind-portion of each segment by a square of green transversed by diagonal lines; a subdorsal stripe white, interrupted at the sutures by light green; ventral stripe and prolegs, rose-red. Feeds on White Pine, and matures about the middle of September, when it enters the ground and forms a cell for pupation."

In the Carnegie Museum, there is one inflated caterpillar from the Holland collection, bearing only the label "Sphinx pineum Lintner", which is not distinct from $L$. bombycoides caterpillars (on the basis of head capsule morphology).

Pupa. Unknown.

Distribution. Butler (1877) and J. B. Smith (1888) reported L. pinea from Canada, but specimens are not available to verify their records.

\section{Discussion}

The two known specimens of this taxon are morphologically intermediate between $L$. coniferarum and $L$. bombycoides, but whether they represent a fourth species of Lapara cannot readily be decided until more material is available for study. Lintner's two specimens are more than 110 years old, and he apparently did not collect others at Schoharie. The country west of the Hudson River and north of the Catskill Mts. was and is frequently visited by collectors of Lepidoptera, and none ever reported $L$. pinea. I know of no sphingids with such a limited distribution, but even so, they would be expected to occur at least at some localities in the vicinity of the type locality. 
For the time being at least Lintner's two specimens cannot be assigned rightly to any known species of Lapara, although they certainly belong to this genus. As they show characteristics of both bombycoides and coniferarum, I strongly recommend that crossbreeding experiments with these two species be undertaken to determine if hybridization is possible. Perhaps Lintner's specimens are nothing more than hybrids and the taxon "pinea" is an invalid one.

\section{Acknowledgments}

The assistance of the following institutions and individuals in making material available for this study is gratefully acknowledged: H. K. Clench, Carnegie Museum; B. Colborne, Ohio State Museum; G. W. Dekle, Florida State Collection of Arthropods; H. E. Evans, Museum of Comparative Zoology; D. C. Ferguson, Yale Peabody Museum of Natural History; W. D. Field, United States National Museum; R. L. Fischer, Michigan State University; J. G. Franclemont, Cornell University; D. F. Hardwick, Canadian National Collection of Insects; A. H. Hayes, British Museum (Natural History); J. R. Holman, Clemson University, South Carolina; F. W. Mead, Florida State Collection of Arthropods; F. H. Rindge, The American Museum of Natural History; W. E. Sieker, Madison, Wisconsin; C. A. Triplehorn, Ohio State University; V. R. Vickery, Lyman Entomological Museum; R. L. Wenzel, Field Museum of Natural History; G. B. Wiggins, Royal Ontario Museum; J. A. Wilcox, New York State Museum, types of L. pinea; A. K. Wyatt, Field Museum of Natural History.

Special thanks are extended to F. H. Rindge, AMNH, who made at the author's request the first dissections of Lapara specimens and so aided in the initiation of this project, and to B. Mather, Jackson, Mississippi, who collected with undiminished enthusiasm over the years many of the Mississippi specimens employed in this study. Thanks are also due to C. F. dos Passos for expert advice concerning the etymology of the name L. halicarnie.

Gratefully acknowledged is the help of A. B. Klots and F. H. Rindge, AMNH, D. F. Hardwick, CNC, G. B. Wiggins, ROM, in critically reading this paper, of T. Yamamoto, ROM, and D. Barr, ROM, in editing the manuscripts. All figures were prepared by A. Odum, scientific illustrator in the Department of Entomology and Invertebrate Zoology, ROM. The photographs were taken by L. Warren, Head Photographer, Department of Photography, ROM. Miss A. Hillmer typed the final manuscript. 


\section{Literature Cited}

ABBOT, J. AND J. E. SMITH

1797 The natural history of the rarer lepidopterous insects of Georgia, ...collected from the observations of Mr. John Abbot. London, J. Edwards, 2 vol., 214 pp., 104 plates.

BELL, T.R.D. AND F. B. SCOTT

1937 The fauna of British India including Ceylon and Burma. Moths. Volume 5: Sphingidae. London, Taylor and Francis, 537 pp., x v plates.

BETHUNE, C.J.S.

1868 Notes on Canadian Lepidoptera. Can. Ent., vol. 1, no. 3, pp. 17-18. BEUTENMÜLLER, $\mathrm{W}$.

1895 Descriptive catalogue of the Sphingidae found within fifty miles of

New York City. Bull. Am. Mus. Nat. Hist., vol. 7, pp. 275-320.

BOISDUVAL, J.-A.

1875 Sphingides, Sésiides, Castnides. In Boisduval, J.-A. and A. Guénée,

Histoire naturelle des insects. Spécies général des lépidoptères héterocères. tome I, (1874). Paris, Libraire Encyclopédique de Roret. $568 \mathrm{pp}$.

BUTLER, A. G.

1877 Revision of the heterocerous Lepidoptera of the family Sphingidae.

Trans. Zool. Soc. Lond. (1876), vol. 9, pt. 10, no. 1, pp. 511-644.

CLARK, B. P.

1919 Some undescribed Sphingidae. Proc. New Engl. Zool. Club, vol. 6, pp. 99-114.

CLEMENS, B.

1859 Synopsis of North American Sphingidae. J. Acad. Nat. Sci. Philad.,

N.S., vol. 4, pt. 2, pp. 97-190.

DARLINGTON, E. P.

1947 Notes on certain types of Lepidoptera described by Brackenridge

Clemens. Trans. Am. Ent. Soc., vol. 73, pp. 85-104.

DRAUDT, M.

1931 Familie Sphingidae. In Seitz, A., Die Gross-Schmetterlinge der Erde,

Volume 6: Die Amerikanischen Spinner und Schwärmer. Stuttgart (1940), Alfred Kernen, pp. 845-900.

DYAR, H. G.

1902 A list of North American Lepidoptera and key to the literature of this order of insects. Bull. U.S. Natn. Mus., vol. 52, pp. 1-723.

FERNALD, C. H.

1886 The Sphingidae of New England. Augusta, Sprague and Son, 85 pp. FORBES, W.T.M.

1923 The Lepidoptera of New York and neighboring states. Primitive forms, Microlepidoptera, Pyraloids, Bombyces. Cornell Univ. Agric. Exp. Stn., Mem. 68, pp. 1-729.

1948 Lepidoptera of New York and neighboring states. Part II, Geometridae, Sphingidae, Notodontidae, Lymantriidae. Cornell Univ. Agric. Exp. Stn., Mem. 274, pp. 1-264. 
GROTE, A. R.

1873 Catalogue of the Sphingidae of North America. Bull. Buffalo Soc. Nat. Sci., vol. 1, pp. 17-28.

1875 Check list of North American Sphinges. Bull. Buffalo Soc. Nat. Sci., vol. 2, pp. 224-228.

1882 New check list of North American moths. New York, N.Y. Ent. Club, 73 pp.

HARRIS, T. W.

1839 Descriptive catalogue of the North American insects belonging to the Linnaean genus Sphinx in the Cabinet of Thaddeus William Harris, M.D., Librarian of Harvard University. Am. J. Sci. Art., vol. 36, pp. 282-320.

1862 A treatise on some of the insects injurious to vegetation. A new edition, ed. by C. L. Flint. Boston, Crosby and Nichols, 640 pp.

HODGES, RONALD W.

1971 The moths of America north of Mexico including Greenland. Fascicle 21. Sphingoidea. Hawkmoths. London, E. W. Classey and R.B.D. Publications, 158 pp.

HOLLAND, W. J.

1903 The moth book. Garden City, New York, Doubleday, Page and Co., $479 \mathrm{pp}$.

HÜBNER, J.

1816-26 Verzeichnis bekannter Schmettlinge. Augsburg, 431 pp., 72 plates.

KIMBALL, C. P.

1965 The Lepidoptera of Florida, an annotated checklist. Arthropods of Florida and neighboring land areas, Volume I. Gainesville, Div. Plant Ind., State Fla. Dep. Agric., 363 pp.

KIRBY, W. F.

1892 A synonymic catalogue of Lepidoptera Heterocera (Moths). Volume

I. Sphinges and Bombyces. London, Gurney and Jackson, $951 \mathrm{pp}$.

KNUDSON, J. P.

1954 Butterflies and conspicuous moths of the Oglethorpe University Campus. Georgia, Oglethorpe University, 13 pp.

KOEBELE, A.

1881 Description of and notes upon various larvae. Bull. Brooklyn Ent. Soc., vol. 4 , no. 3 , pp. 20-22.

LINTNER, J. A.

1864 Notes on Sphingidae of the State of New York. Proc. Ent. Soc. Philad., vol. 3, p. 669.

1872 Description of a new Sphinx. 23rd A. Rep. N.Y. St. Cab. Nat. Hist., app. D. Ent. Contr., pp. 37-39.

MARTYN, TH.

1797 Psyche, or figures of nondescript Lepidopterous insects or rare moths and butterflies from different parts of the world. London, 32 plates. 
MCGUGAN, B. M.

1958 Forest Lepidoptera of Canada, Volume I. Canada Dep. Agric. Publ. 1034, 76 pp.

MOOSER, O.

1940 Fauna Mexicana. III. Enumeración de los Esfíngidos Mexicanos (Insecta: Lepidóptera) con notas sobre su Morfología y su distribu ción en la República. An. Esc. Noc. Cien. Biol., (1939), vol. 1, pp. 407-495.

MORRIS, J. G.

1862 Synopsis of the described Lepidoptera of North America. Washington, Smithsonian Institution, $358 \mathrm{pp}$.

MOSHER, E.

1918 Pupae of common Sphingidae of eastern North America. Ann. Ent. Soc. Am., vol. 11, pp. 403-442.

PACKARD, A. S.

1890 Insects injurious to forest and shade trees. 5th Rep. U.S. Entomol. Commission. Washington, U.S. Dep. Agric., 957 pp.

ROTHSCHILD, W. AND K. JORDAN

1903 A revision of the lepidopterous family Sphingidae. Novit. Zool., vol. 9, suppl., 972 pp., 67 plates.

1907 Family Sphingidae. In Wytsman, P.A.G. Genera insectorum. Lepidoptera, fasc. 57. Brussels, V. Verteneuil and L. Desmet, 157 pp.

SMITH, J. B.

1888 A monograph of the Sphingidae of America, north of Mexico. Trans. Am. Ent. Soc., vol. 15, pp. 49-242.

STRECKER, $\mathrm{H}$.

1872-77 Lepidoptera, Rhopaloceres and Heteroceres, indigenous and exotic; descriptions and coloured illustrations. Reading, Pa., Owen's Steam Book and Job Printing Office, 143 pp.

1880 Descriptions of some new species and varieties of North American Lepidoptera. Bull. Brooklyn Ent. Soc., vol. 3, no. 5, pp. 33-36.

1900 Lepidoptera, Rhopaloceres and Heteroceres, indigenous and exotic; descriptions and coloured illustrations, Supplement No. 3. Reading, Pa., Owen's Steam Book and Job Printing Office, 13-38 pp.

WAGNER, H.

1913 Lepidopterorum Catalogus. Pars 12: Sphingidae-subfamily Acherontiinae. Berlin, W. Junk, 77 pp.

WALKER, F.

1856 List of the specimens of Lepidopterous insects in the collection of the British Museum. Part VIII: Sphingidae. London, British Museum, $271 \mathrm{pp}$.

1864 List of the specimens of Lepidopterous insects in the collection of the British Museum. Part XXXI, Supplement. London, British Museum, $321 \mathrm{pp}$. 
Figs. 1-5 Adult structures.

Fig. 1 Frontal view of denuded head (diagrammatic): a) L. halicarnie. $b$ ) L. coniferarum; c) L. bombycoides.

Fig. 2 Ventral view of denuded head (diagrammatic): $a$ ) L. halicarnie; $b$ ) L. coniferarum;c) L. bombycoides.

Fig. 3 Labial palpus, second and third segments: a) L. halicarnie (AMNH 11,353 ơ, Sewall, Florida, 6 February 1948; ROM 9-180 q, Florida, no date); b) L. coniferarum (ROM 9-037 ó, Pearl, Mississippi, 11 June 1960); c) L. bombycoides (AMNH 11,373 o, L. Kejimkuiik, Nova Scotia, 19 June 1957).

Fig. 4 Epiphysis of anterior leg: a) L. halicarnie (A MNH 11,353 o, Sewall, Florida, 6 February 1948); b) L. coniferarum (ROM 9-039 o', Jackson, Mississippi, 11 June 1960); c) L. bombycoides (AMNH 11,373 ơ, L. Kejimkujik, Nova Scotia, 19 June 1957).

Fig. 5 Pretarsus of anterior leg: a) L. halicarnie (AMNH 11,353 o, Sewall, Florida, 6 February 1948); b) L. bombycoides (ROM 9-159 d, White Point Beach, Nova Scotia, 24 June 1953). 

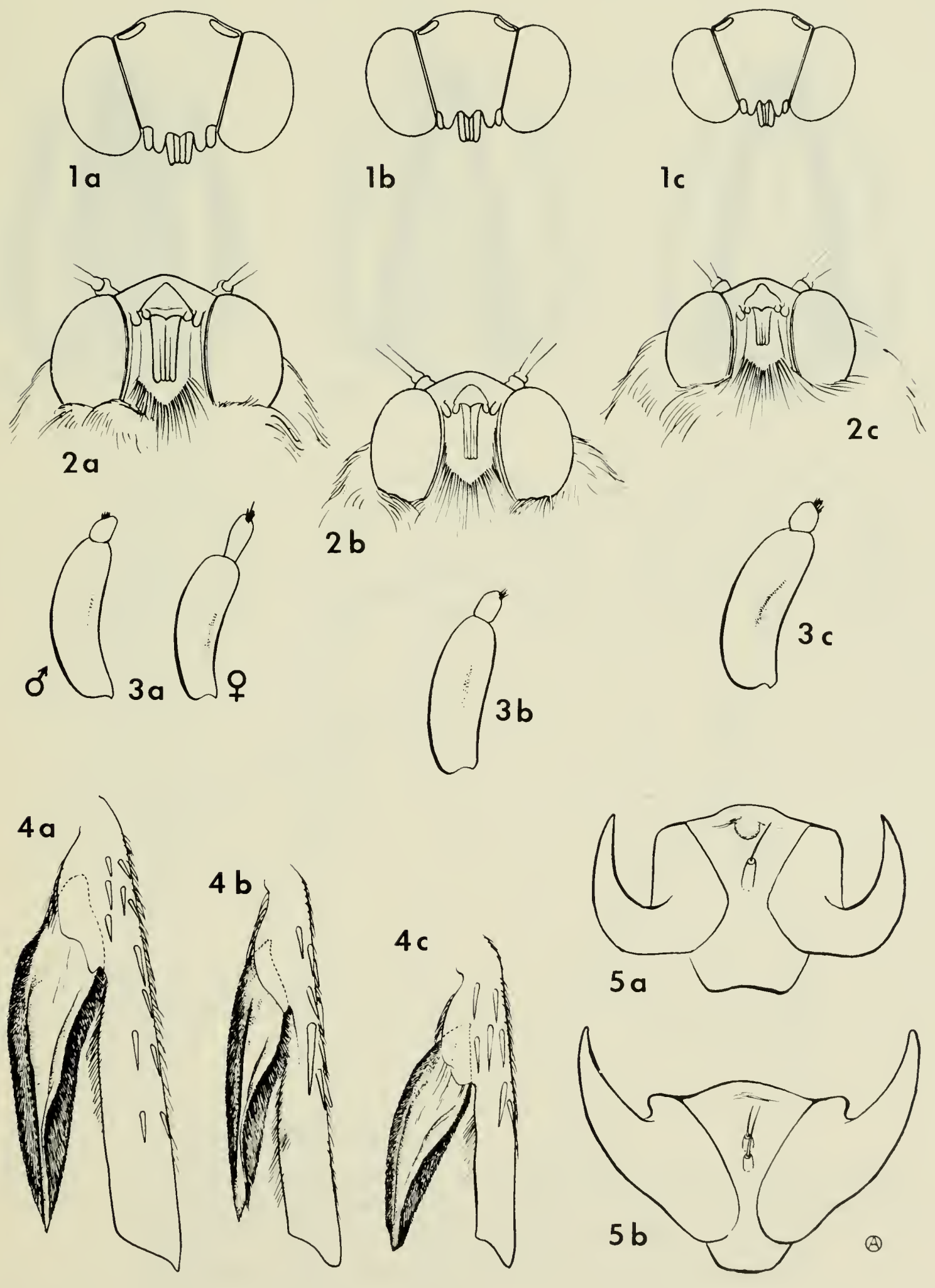

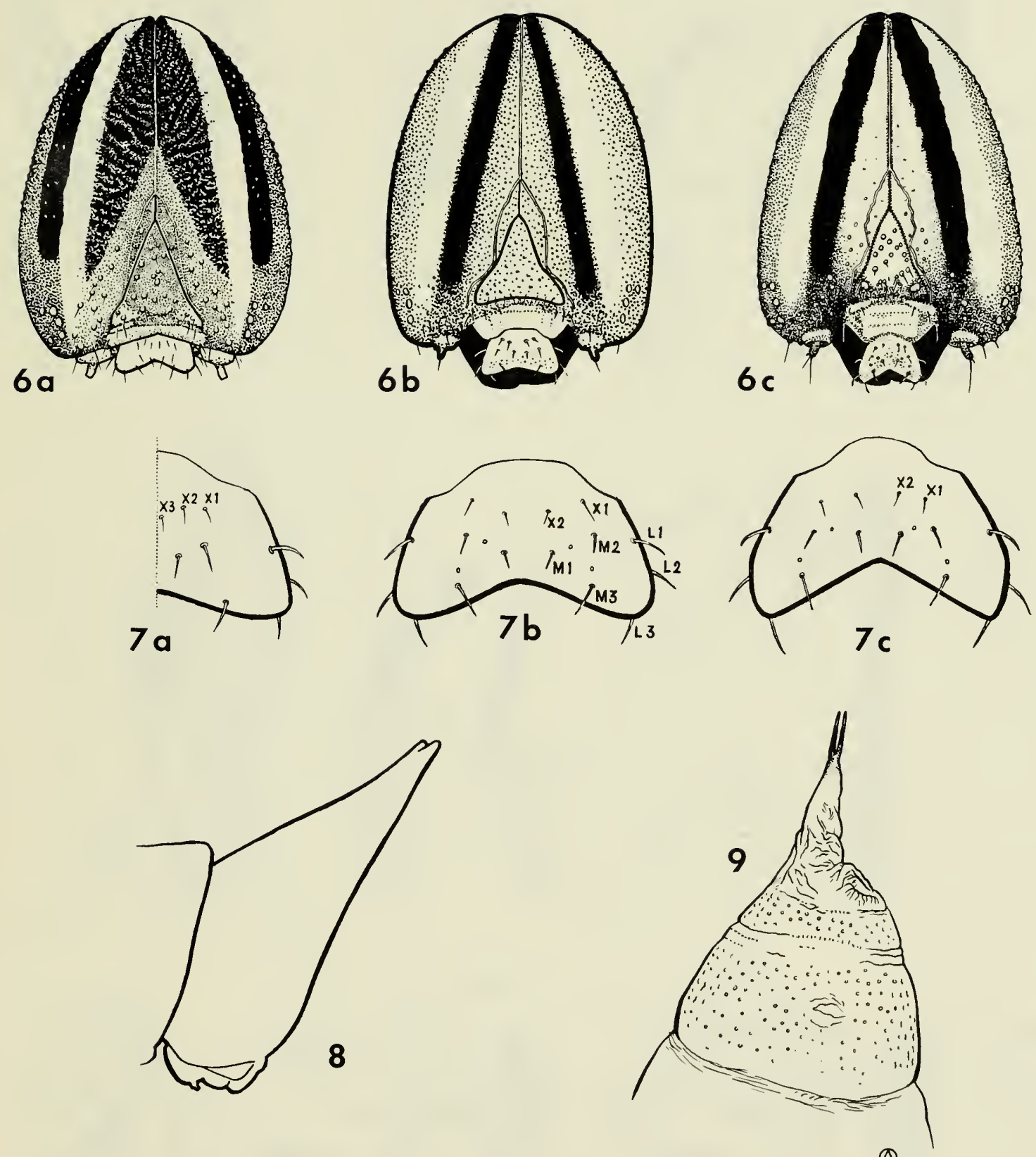

(4)

Figs. 6-9 Larval and pupal structures.

Fig. 6 Larval headcapsules. a) L. halicarnie (CM, inflated larva, no data); b) L. coniferarum (FSCA, larva in alcohol, Perry, Florida, 30 September 1958, on Pinus taeda); c) L. bombycoides (FSCA, larva in alcohol, Perry, Florida, 30 April 1959, on Pinus taeda).

Fig. 7 Setal groups on larval labrum of the three specimens of Fig. 6.

Fig. 8 L. coniferarum (FSCA, larva in alcohol, fourth instar, Sanford, Florida, 10 March 1961, on Pinus longifolia).

Fig. 9 L. bombycoides (ROM, cremaster of pupa in alcohol, ex ovo, Kendal, Ontario, 10 September 1967). 
Figs. 10-14 Male genitalia.

Fig. 10 Entire structure of L. bombycoides (ROM 9-157 d, Chaffeys Locks, Ontario, 3 July 1964), ventral view.

Fig. 11 L. halicarnie (AMNH 11,353 o, Sewall, Florida, 6 February 1948):

a) entire left valve, medial view; $b$ ) process of sacculus, lateral view;

c) process of sacculus, ventral view; $d$ ) aedoeagus.

Fig. 12 L. coniferarum (ROM 9-037 o, Pearl, Mississippi, 11 June 1960): a) left valve, medial view; $b$ ) process of sacculus, lateral view; $c$ ) process of sacculus, ventral view with two outline drawings of same view illustrating variation; $d$ ) aedoeagus.

Fig. 13 L. bombycoides (AMNH 11,373 o, L. Kejimkujik, Nova Scotia, 19 June 1957): $a$ ) left valve, medial view; $b$ ) process of sacculus, lateral view; $c$ ) process of sacculus, ventral view; $d$ ) aedoeagus.

Fig. 14 "L. pinea" (NYSM ot type, no further data): a) left valve, medial view; $b$ ) aedoeagus. 

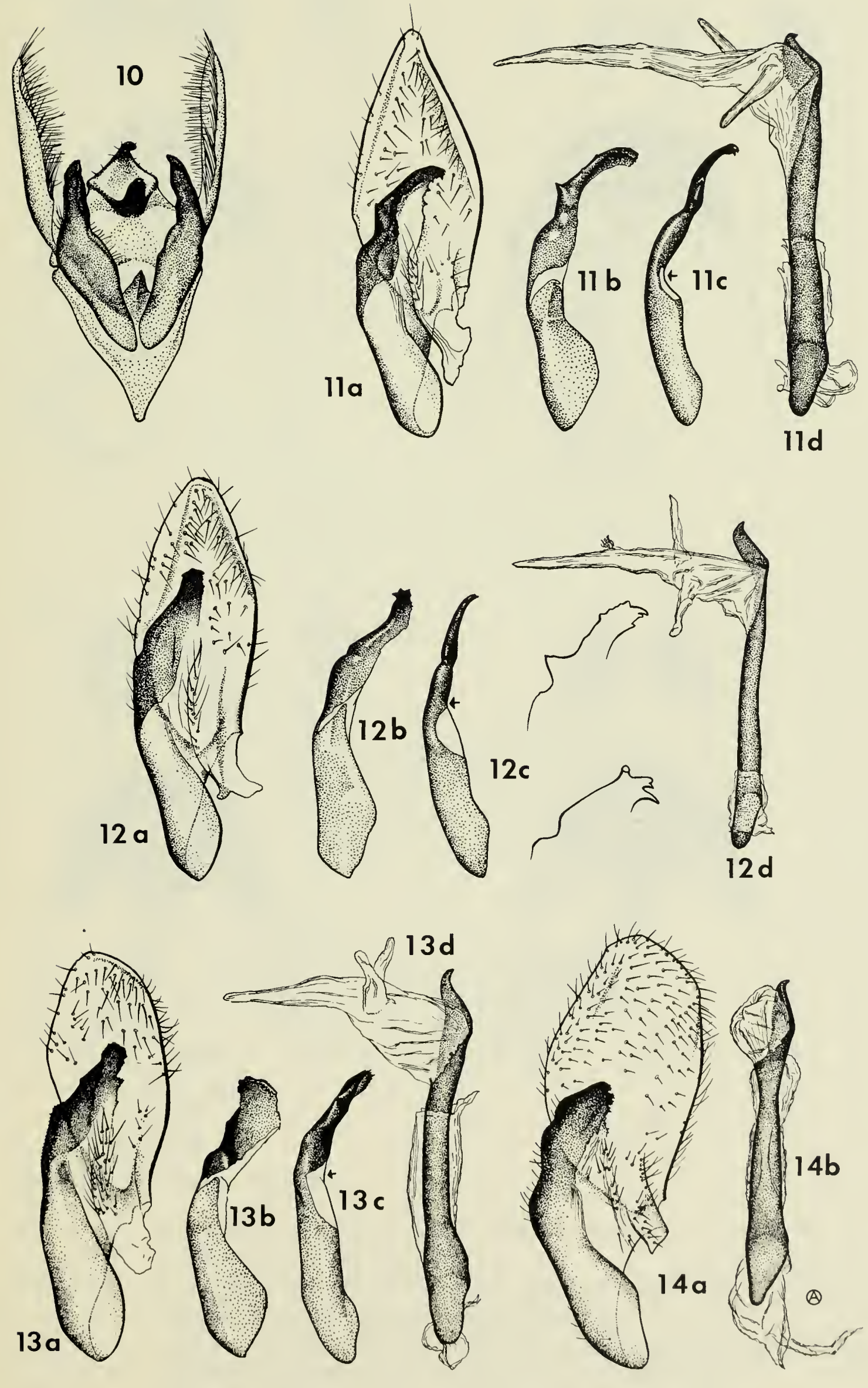

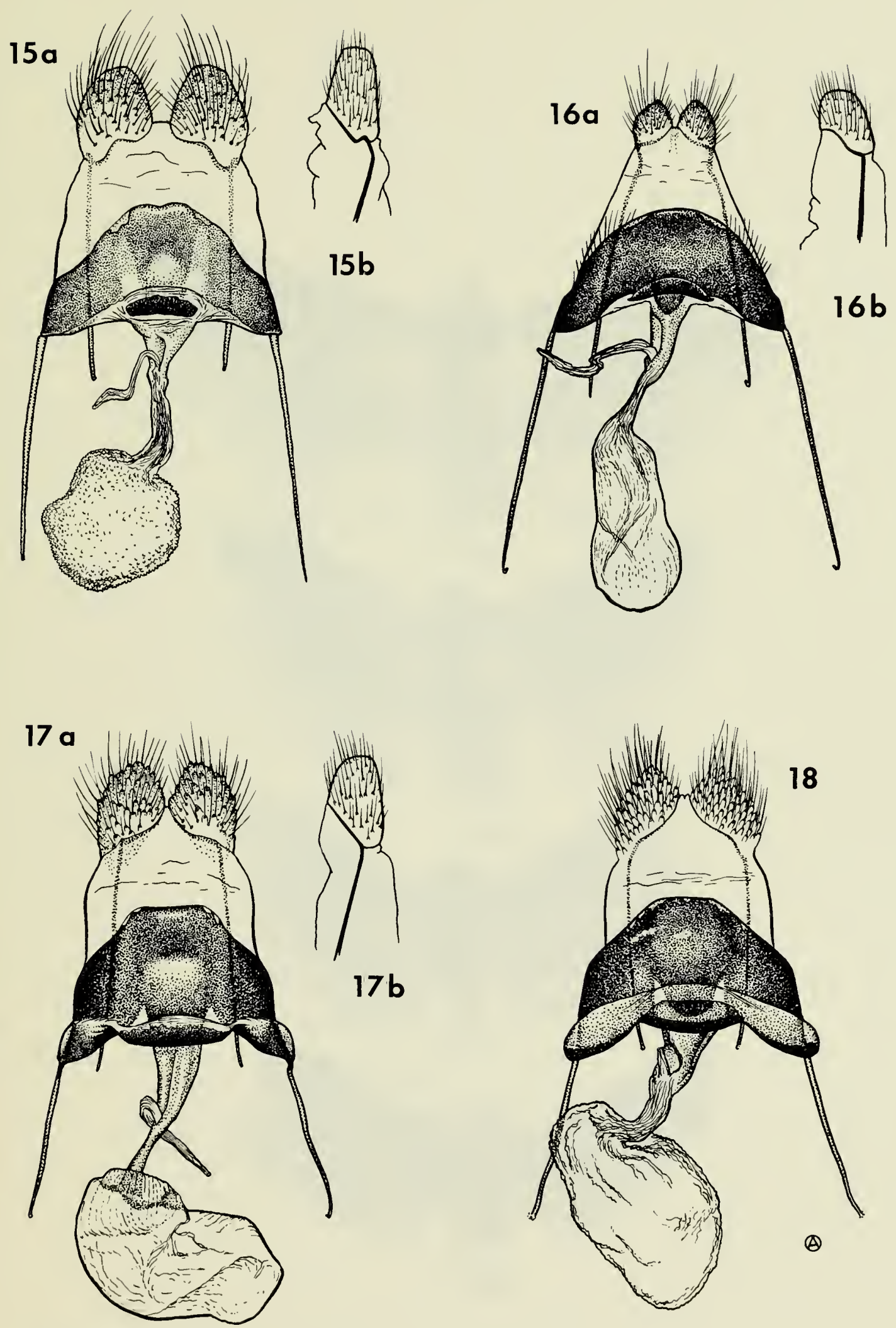

Figs. 15-18 Female genitalia.

Fig. 15 L. halicarnie (ROM 9-180 , Florida, no date): $a$ ) ventral view; $b$ ) ovipositor valve, lateral view.

Fig. 16 L. coniferarum (ROM 9-179 , Baltimore, Maryland, 25 June): $a$ ) ventral view; $b$ ) ovipositor valve, lateral view.

Fig. 17 L. bombycoides (ROM 9-177 , One Sided Lake, Ontario, 5 July 1962): $a$ ) ventral view; $b$ ) ovipositor valve, lateral view.

Fig. 18 "L. pinea" (NYSM $\$$ type, no further data), ventral view. 

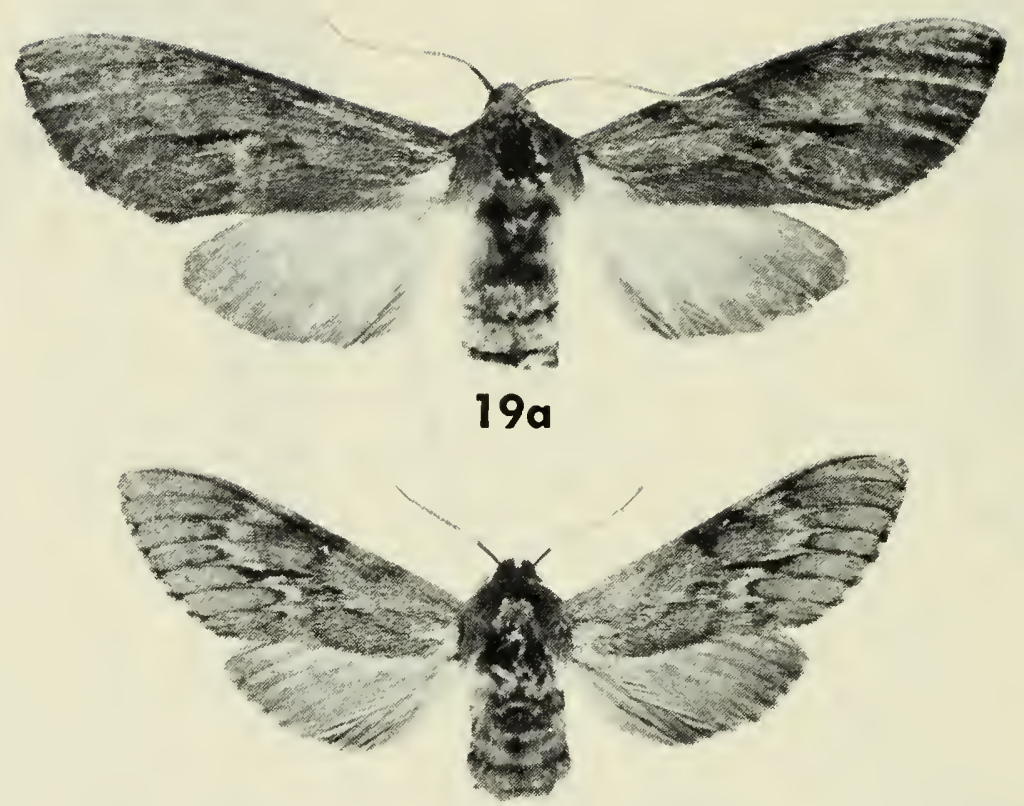

$19 b$

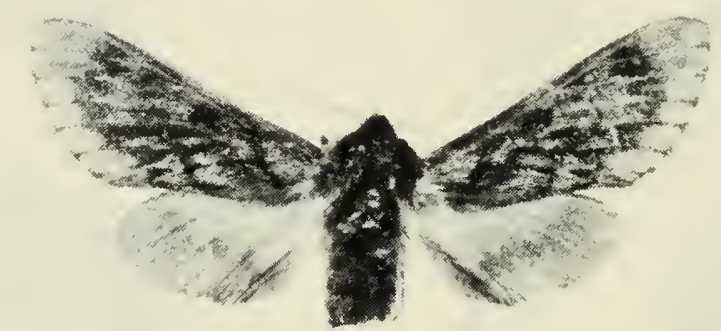

19c

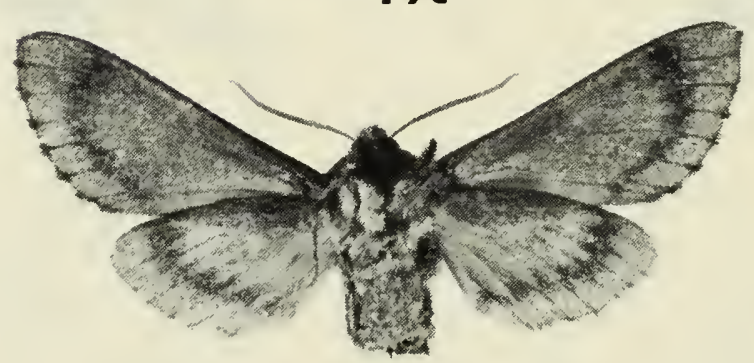

19d

Fig. 19 Adult moths. a) L. halicarnie (AMNH 11,353 o, Sewall, Florida, 6 February 1948); b) L. coniferarum (AMNH 11,367 o , Lakehurst, new Jersey, 21-31 May); c) L. bombycoides (AMNH 11,373 o, L. Kejimkujik, Nova Scotia, 19 June 1957), dorsal view; $d$ ) same, ventral view. 

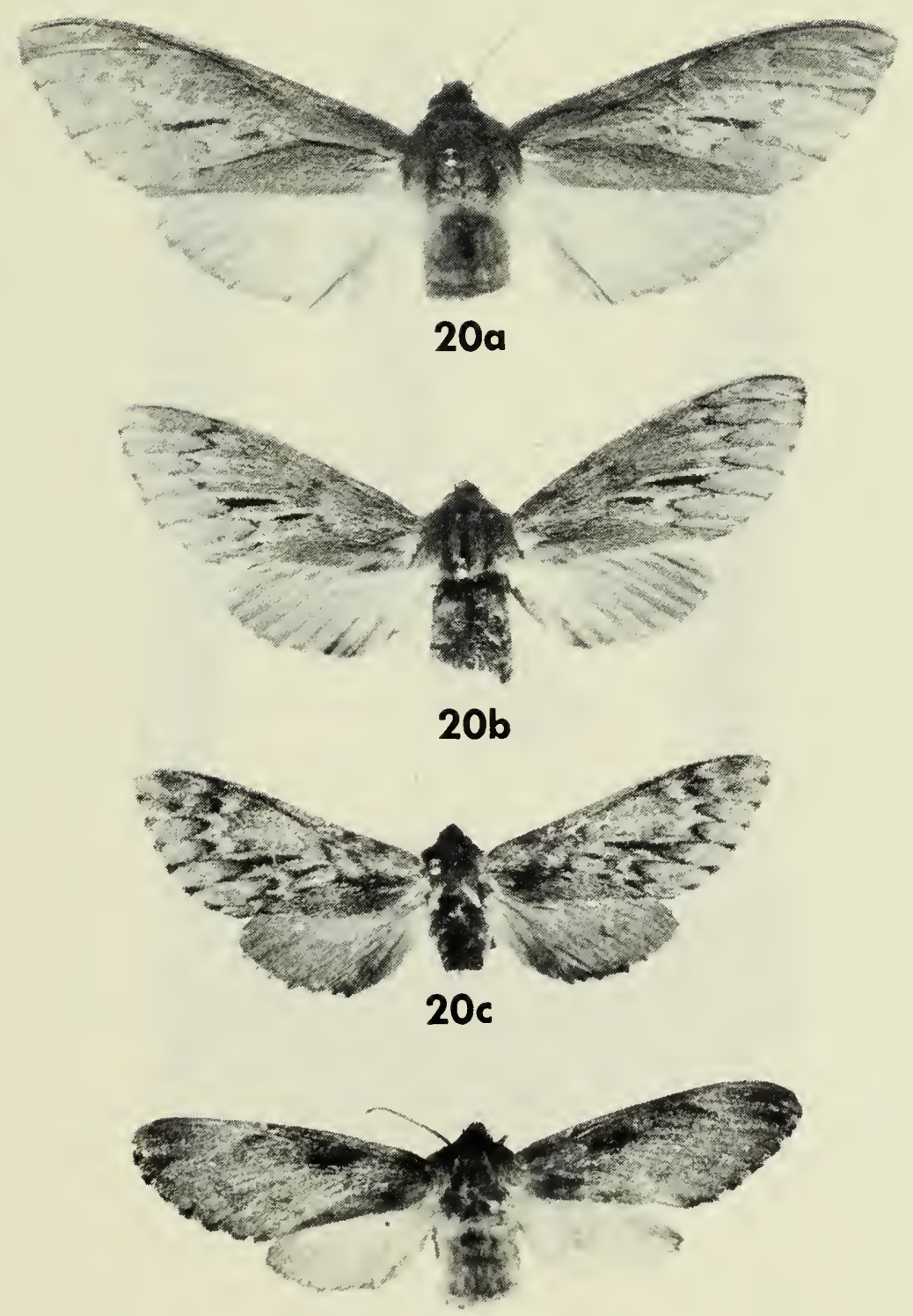

20d

Fig. 20 Adult moths. a) L. halicarnie (ROM 9-180 , Florida, no date); $b$ ) L. coniferarum (ROM 9-124 9 , Florida, no date); c) L. bombycoides (ROM 9-210 \%, Chaffeys Locks, Ontario, 13 July 1963); d) "L. pinea" (NYSM + type, no further data). 


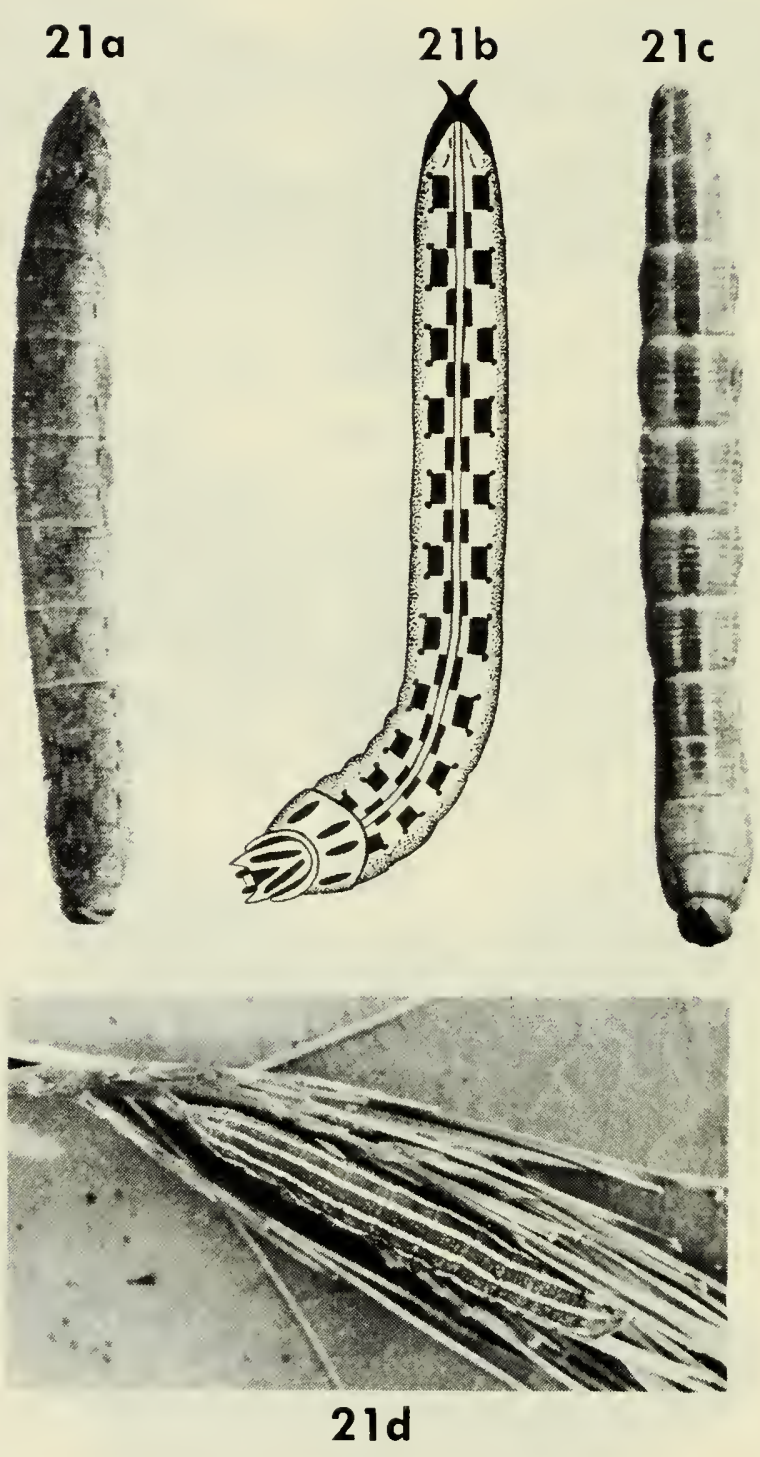

Fig. 21 Larvae. a) L. halicarnie (CM inflated larva, no data); b) $L$. halicarnie (copy of Abbot's drawing (1797: pl. XLII)); c) $L$. coniferarum (CM inflated larva, no data); d) L. bombycoides (ROM in alcohol, live photograph by J.C.E. Riotte, Kendal, Ontario, 3 September 1967). 



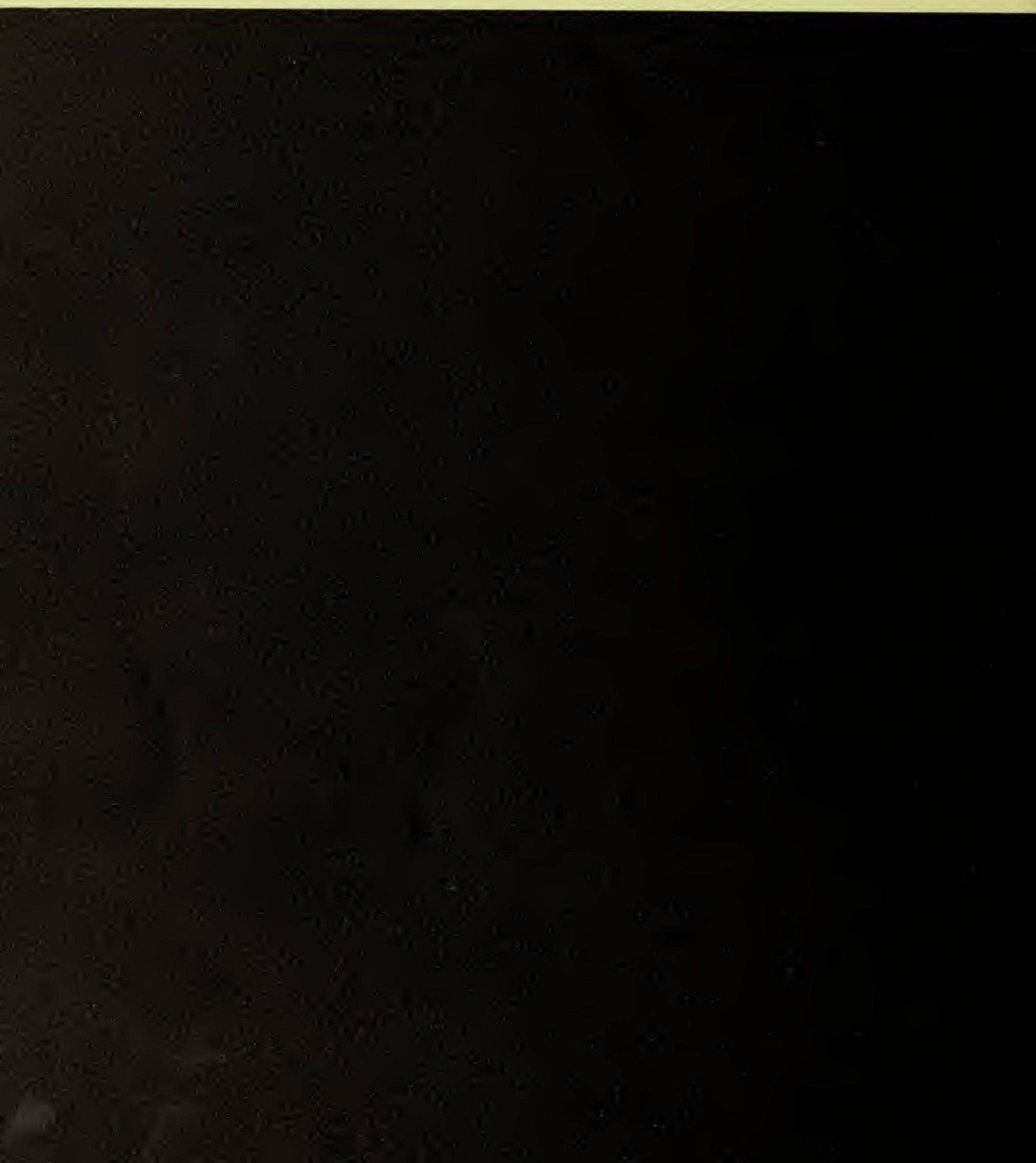

